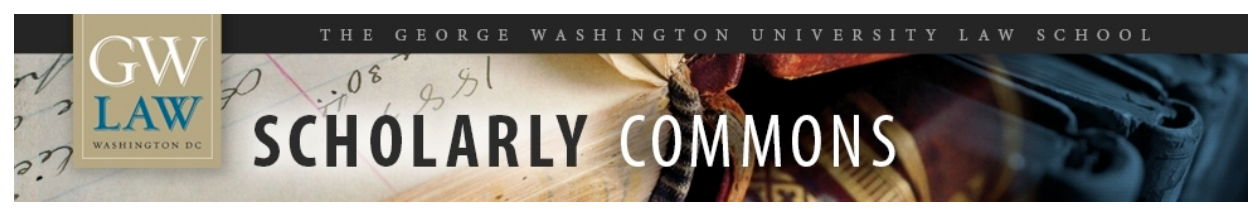

\title{
Why Black Homeowners are More Likely to Be Caribbean- American than African-American in New York: A Theory of How Early West Indian Migrants Broke Racial Cartels in Housing
}

\author{
Eleanor Marie Brown \\ George Washington University Law School, eub226@psu.edu
}

Follow this and additional works at: https://scholarship.law.gwu.edu/faculty_publications

Part of the Law Commons

\section{Recommended Citation}

Brown, Eleanor Marie, Why Black Homeowners are More Likely to Be Caribbean-American than AfricanAmerican in New York: A Theory of How Early West Indian Migrants Broke Racial Cartels in Housing (June 23, 2016). GWU Legal Studies Research Paper No. 2016-23; GWU Law School Public Law Research Paper No. 2016-23. Available at SSRN: http://ssrn.com/abstract=2799698

This Article is brought to you for free and open access by the Faculty Scholarship at Scholarly Commons. It has been accepted for inclusion in GW Law Faculty Publications \& Other Works by an authorized administrator of Scholarly Commons. For more information, please contact spagel@law.gwu.edu. 
WHY BLACK HOMEOWNERS ARE MORE LIKELY TO BE CARIBBEANAMERICAN THAN AFRICAN AMERICAN IN NEW YORK: A THEORY OF HOW EARLY WEST INDIAN MIGRANTS BROKE RACIAL CARTELS IN HOUSING ELEANOR MARIE LAWRENCE BROWN*

\begin{abstract}
Why are the black brownstone owners in Harlem and Brooklyn disproportionately West Indian? The landlords, West Indian-American? The tenants African-American? These are tough questions. For students of housing discrimination, West Indian Americans have long presented a quandary. If it is reasonable to assume that racial exclusions are being consistently applied to persons who are dark-skinned, one would expect to find that housing discrimination has had similar effects on West IndianAmericans and African-Americans. Yet this is not the case: West IndianAmericans generally own and rent higher quality housing than AfricanAmericans.
\end{abstract}

Moreover, these advantages began long ago. For example, when racial covenants, that is, restrictions barring racial and ethnic groups from owning real property in particular neighborhoods were rife in New York, they were not consistently applied against West Indians, who were sometimes able to

* Eleanor Marie Lawrence Brown, GWIPP Fellow (2013) and Associate Professor of Law (with tenure), George Washington University Law School; J.D., Yale Law School (1999); M.Phil. Politics, Oxford (1997) (Rhodes Scholar). Former Schwartz Fellow, New America Foundation; Former Chairman of the Jamaica Trade Board; Former Reginald Lewis Fellow, Harvard Law School; Former Law Clerk to the Honorable Patricia Wald (ret.), U.S. Court of Appeals for the District of Columbia Circuit; Former Law Clerk to the Honorable Keith Ellison, U.S. District Court for the Southern District of Texas. I have benefited from the Property colloquium at George Mason Law School. Comments received at the Lutie Lytle Conference for Black Female Legal Scholars were particularly helpful. I have also benefited from conversations with or comments from Kendall Thomas, Olati Johnson, Dorothy Roberts, Bernadette Atuahene, Lee Fennell, Guido Calabresi, Frank Upham, Sonya Katyal, Dan Kelly, Paul Butler, Marcella David, Dan Sharfstein, Paulette Caldwell, Mary Dudziak, Nestor Davidson, Ruth Okediji, Jill Hasday, Scott Kieff, Hari Osofsky, Dan Sokol, Camille Gear, Karen Brown, Kevin Johnson, Charles Ogletree, Ken Mack, Steve Legomsky, Beverly Moran, Jim Coleman, Nicole Garnett, Kimani Paul-Emile, Brad Snyder, Devon Carbado, Aubrey Bonnett, Calvin Holder, Eduardo Peñalver, Joe Singer, Henry Smith, Richard Brooks, David Martin, Peter Henry, Angela Banks, Angela OnwuachiWillig, Tomiko Brown-Nagin, Audrey McFarlane, Lant Pritchett, Dillon Alleyne, Neville Lewis, Tony Harriott, Richard Bernal, Eric Posner, Sylvia Lazos, Alison Tirres, Deep Gulasekaram, Naomi Cahn, David Fontana, Carol Rose, Robert Ellickson, Claire Priest, Rose Villazor, Wendy Greene, Ernesto Hernandez-Lopez, Renee Lerner, Jackie Ross, Maximo Langer, Kim Lane Scheppele, Eric Claeys, Jerry Davila, Daniel Hamilton, and Bob Cottrol. I am grateful to the librarians and/or archivists at the University of the West Indies. Finally, I am grateful for the aid of my research assistants, Jared Stipelman, Shanellah Verna and Jenna Brofsky. 
buy into tony neighborhoods. While it is true that such covenants were also inconsistently applied against other ethnic and religious groups such as Jewish New Yorkers, West-Indians still stand out. Since West Indians are overwhelmingly dark-skinned persons of African descent they typically did not have the option of "passing" that may have been available to other groups.

Eschewing more traditional explanations in the civil rights literature, I apply the literature in which racial segregation in real property ownership is conceived as a racial monopoly in which racial cartels appropriate anticompetitive techniques to monopolize access to real property. Maintaining a racial cartel is dependent on white owners maintaining a united front, that is, they must uniformly refuse to sell. Importantly, realtors play a gatekeeping role in real estate and West Indians dominated the realtor sector. As realtors, they were expert at finding defectors, namely, whites willing to break norms of racial exclusivity, in exchange for their ability to extract a premium for selling to blacks early. Brokers then proceeded to buy significant numbers of titles, which were then off-loaded to fellow West Indians. West Indian brokers could act in confidence because they had cashrich clients and were often buying in trust (de-facto if not de-jure) for fellow West Indians.

In so doing, West Indian brokers in New York were simply replicating techniques that had been utilized by their land-brokering ancestors. I discuss the history that "previews" this period in New York, albeit in a different context: in the British West Indian islands from the migrants originated. There are repeated instances of blacks "busting" white monopolies in landownership, throughout the West Indian colonies in contravention of racial norms in the British colonies of who was allowed to own land where. Upon arrival in New York, West Indians encountered another racial monopoly in real property ownership, namely Northern racial segregation. They essentially appropriated the same techniques that they had utilized in the West Indies to break into white neighbourhoods in New York. 


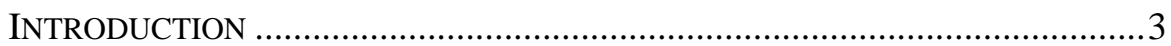

I. PERFORMATIVE THEORIES ................................................................. 10

II. HOW WEST INDIANS CAME TO BUY INTO WHITE NEIGHBORHOODS 13

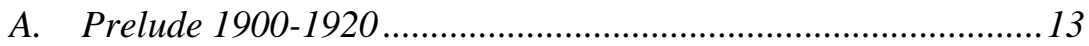

B. 1920 onwards: Racial cartelization …….................................... 13

C. White defection ........................................................................ 17

D. Anecdotal evidence to support this theory: What we know from

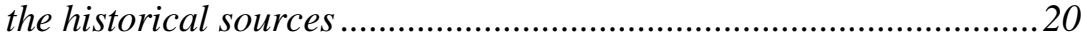

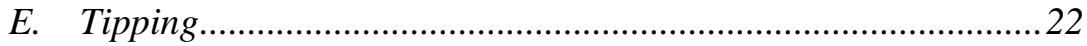

F. Related factors that allowed West Indians to quickly consolidate

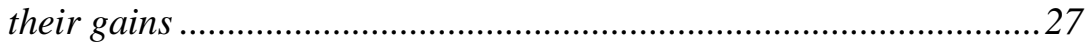

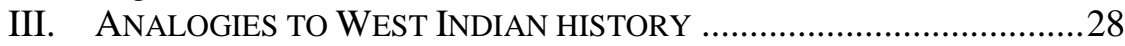

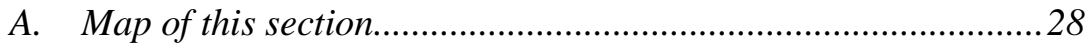

B. The Prelude: Property during Slavery .......................................30

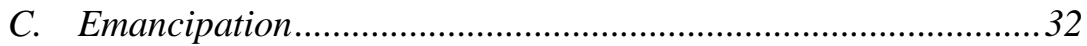

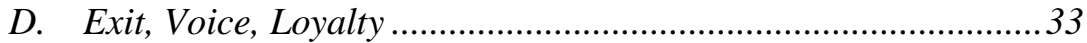

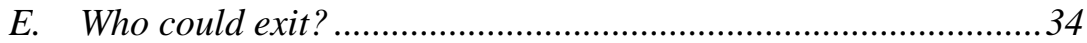

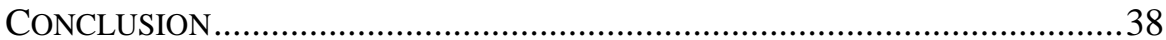

\section{INTRODUCTION}

Why are the black brownstone owners in Harlem and Brooklyn disproportionately West Indian? ${ }^{1}$ The landlords, West Indian-American? The tenants African-American? ${ }^{2}$ These are tough questions. ${ }^{3}$ For students of

\footnotetext{
1 RONALD SCHMIDT SR., ET AL., NEWCOMERS, OUTSIDERS, AND INSIDERS: IMMIGRANTS AND AMERICAN RACIAL POLITICS IN THE EARLY TwENTY-FIRST CENTURY 111 (2009); Kyle D. Crowder, Residential Segregation of West Indians in the New York/New Jersey Metropolitan Area: The Role of Race and Ethnicity, 33 INT'L MIGRATION REV. 79 (1999); see also EMILY ROSENBAUM \& SAMANTHA FRIEDMAN, THE HOUSING DIVIDE: HOW GENERATIONS OF IMMIGRANTS FARE IN NEW YORK'S HOUSING MARKET (2007).

${ }^{2}$ Of course, there is a long and fraught history of discrimination against African Americans in realproperty ownership both in the post-bellum South and in the North after the Great Migration. Some relevant articles in the legal scholarship are summarized in Footnote 111, infra. For articles discussing comparative housing patterns between West Indians and African Americans, see Kyle D. Crowder \& Lucky Tedrow, West Indians and the Residential Landscape of New York City, in ISLANDS IN THE CITY: WeST INDIAN MigRATION TO NEW YORK (Nancy Foner ed., 2001); Arun Peter Lobo \& Joseph J. Salvo, The Newest New Yorkers, 2000: Immigrant New York in the New Millenium, 1999; Rosenbaum AND Friedman, supra note 1, Philip KASINITZ, CARIBBEAN New YORK: BLACK IMMIGRANTS AND THE POLITICS OF RACE 90-95 (Ithaca: Cornell University Press 1992), PAULE MARSHALl, BROWN GIRL, BROWNSTONES (1981).

${ }^{3}$ There is a significant background literature on West Indian success, with several sources discussing the property markets. See, e.g., Winston James, Explaining Afro-Caribbean Social Mobility in the United States: Beyond the Sowell Thesis, 44 ComP. STUD. IN SOC'Y \& HIST. 218 (2002) [hereinafter James, Explaining Afro-Caribbean Social Mobility]; see also Winston James,
} 
housing discrimination, West Indian Americans have long presented a quandary. ${ }^{4}$ West Indians, like African Americans, are overwhelmingly dark skinned persons of African descent who were enslaved (albeit in the West Indies rather than the United Sates) and are phenotypically indistinguishable from African-Americans. ${ }^{5}$ Thus, if it is reasonable to assume that racial exclusions are being consistently applied to persons who are dark-skinned, one would expect to find that housing discrimination has had similar effects

New Light on Afro-Caribbean Social Mobility in New York City, A Critique of the Sowell Thesis, in New CARIBbeAn Thought: A READER (Brian Meeks \& Folke Lindahl eds., 2001) [hereinafter James, New Light on Afro-Caribbean Social Mobility]; IRA DE A. ReID, THE NEGRo IMMIGRANT: His BACKGRound, CHARACTERISTICS, AND Social ADJustMENT, 1899-1937 (Arno Press 1969) (1939); NAthan Glazer \& Daniel Patrick Moynihan, Beyond the Melting Pot (1970); ETHNICITY: THEORY AND EXPERIENCE (Nathan Glazer \& Daniel Patrick Moynihan eds., 1975).

${ }^{4}$ ROSENBAUM AND FRIEDMAN, supra note 1 at 121.

${ }^{5}$ I will regularly refer to two groups of Blacks. The first group, African Americans (often pithily referred to in the literature as "native" Blacks), includes those descended from Africans who were enslaved here in the United States. The second group, West Indians, has a different historical heritage. These are persons who were enslaved in the West Indies but were not enslaved in the United States and who later became migrants to the United States, mostly after the abolition of slavery in the United States. The term "West Indians" as utilized in this Article does not generally include West Indian immigrants to the United States of other ethnic backgrounds. See Calvin B. Holder, West Indies: Antigua, Bahamas Barbados, Grenada, Guadeloupe, Guyana, Martinique, St. Kitts, Trinidad, in THE NeW AMERICANS: A GuIDE To IMMIGRATION SinCE 1965, at 674-75 (Mary C. Waters \& Reed Ueda eds., 2007 (describing the migration of West Indians to the United States and identifying the group as racially diverse, but predominantly Black). In this Essay, I utilize the term "black" West Indian - as opposed to Afro-West Indian or African-West Indian. In this context, the term "black" West Indian refers only to West Indians of African descent and does not include, for example, West Indians who belong to other racial minority groups, such as persons of East Indian heritage were sometimes referred to as "black" in the United Kingdom (to whom the West Indian colonies largely belonged at the time). Winston James has a comprehensive statistical summary of pre-1965 black immigration to the U.S. by region of origin. Early black immigrants were overwhelmingly of Caribbean origin. Prior to World War II, blacks known as "British West Indians" appeared to outnumber all other black migrant groups by a large margin, with Jamaica, the most populated British West Indian island, supplying the largest number of immigrants. I use the term "British West Indies," "West Indies" or "West India" in the sense in which it is typically used in the historical literature, namely to refer to the Caribbean islands in the Greater and Lesser Antilles. These include Antigua and Barbuda (which were governed by the British as a political unit), St. Kitts and Nevis (same), St. Vincent and the Grenadines (same), Trinidad and Tobago (same), Barbados, St. Lucia, Dominica, Grenada, Jamaica, and Guyana.Indeed, Jamaicans have been the largest group of black Caribbean immigrants for some time, only recently being overtaken by Nigerians. See, James, Explaining Afro-Caribbean Social Mobility, supra note 3. 
on West Indians ${ }^{6}$ and African-Americans. ${ }^{7}$ As one author notes, "levels of segregation suggest that the housing and neighborhood characteristics of African Americans and West Indians should be indecipherable."

Yet, this is not the case. West Indian neighborhoods are distinguishable from African American neighborhoods. Take, for example, indices of segregation. West Indians occupy neighborhoods with lower indices of segregation than African Americans. ${ }^{9}$ West Indians also occupy better quality rentals and own better quality homes than African Americans. ${ }^{10}$

These statistical patterns are less surprising where West Indian households earn more than African American householders. ${ }^{11}$ In a Harpers cover story, James Traub noted that West Indians seemed to place significant value not only on home ownership, but indeed on owning many homes. ${ }^{12} \mathrm{He}$ interviewed West Indians of apparently modest means, who had worked multiple jobs, to acquire multiple homes. ${ }^{13}$ For example, one blue-collar couple had acquired an apartment building; the rental income was then used to acquire further buildings. ${ }^{14}$ West Indian success patterns merited a frontpage story in the New York Times. ${ }^{15}$ When the finding that black per-capita income in certain sections of Queens, New York exceeded white per-capita income elicited nationwide news coverage, sociologists in-the-know recognized that the blacks in question were home-owning middle-class West Indians. ${ }^{16}$

${ }^{6}$ I utilize the definition of West Indians that is conventionally used in the sociological literature, namely, Anglophone (formerly British-colonized) Caribbean nationals. The migrants were overwhelmingly descendants of slaves and "coloreds." The sociologist-historian Orlando Patterson provides a summary of the significance of the West Indies from which the migrants originated and its social structure as follows:

"The sugar plantations, which became all-important by the turn of the eighteenth century, made the Afro-Caribbean societies the richest areas of the world. They also set the basic social structure and tone of these societies. African slaves were brought in on a large scale, resulting in the early demographic dominance of black people. Ruling them was a small minority of white planters . . . Between masters and slaves a third group soon emerged-the coloreds or people of mixed ancestry. This group formed a useful racial and socio-cultural buffer between the whites and blacks. By the end of the eighteenth century a substantial number of them were freedmen." See Orlando Patterson, Context and Choice in Ethnic Allegiance: A Theoretical Framework and Caribbean Case Study, in ETHNICITY: THEORY AND EXPERIENCE, supra note 3 [hereinafter Patterson, Ethnic Allegiance].

${ }^{7}$ ROSENBAUM AND FRIEDMAN, supra note 1 at 118.

${ }^{8} \mathrm{Id}$. at 121 .

${ }^{9} I d$. at 119.

${ }^{10} I d$. at 121 .

${ }^{11} I d$. at 118.

${ }^{12}$ James Traub, You Can Get It If You Really Want, HARPER's, June 1982.

${ }^{13} \mathrm{Id}$.

${ }^{14} I d$.

${ }^{15}$ See Sam Roberts, In Middle-Class Queens, Blacks Pass Whites in Household Income, N.Y. TIMES (June 6, 1994), http://www.nytimes.com/1994/06/06/nyregion/in-middle-class-queensblacks-pass-whites-in-household-income.html; see also Sam Roberts, Blacks Incomes Surpass Whites in Queens, N.Y. TIMES (Oct. 1, 2006),

http://www.nytimes.com/2006/10/01/nyregion/01 census.html?pagewanted=all\&_r=0.

${ }^{16}$ Rosenbaum and Friedman, supra note 1. 
But even when researchers control for income, the West Indian advantage in housing stock appears to persist. ${ }^{17}$ Thus, there may be other factors at play. For example, one sociological study contends that "the tendency of West Indian households to occupy better quality housing and neighborhoods than African Americans directly results from their relative concentration in formerly middle-class white neighborhoods that had stocks of owner-occupied homes. ${ }^{18}$ That is, West Indians were more likely to buy into "solid" white neighborhoods. Moreover, West Indians have long dominated the black realtor sector. ${ }^{19}$ Given the "gatekeeper" role played by realtors, one cannot help wondering whether West Indians have had advantages in mitigating the effect of housing discrimination that have typically not been available to African Americans. ${ }^{20}$

There are good reasons for this suspicion, although the evidence is largely anecdotal. In the article that arguably launched Malcolm Gladwell's career, he reflects on the employment trajectory of his Jamaican co-ethnics shortly after their arrival from the West Indies in 1920 New York. ${ }^{21}$ Like many immigrants of the time, many sought jobs in garment factories. ${ }^{22}$ These garment factories were typically segregated; moreover, the segregation was deeply institutionalized as evidenced by the existence of separate unions for black and white garment workers. ${ }^{23}$ Yet, Gladwell's West Indian subjects sought and received jobs in factories where signs were posted stating "Negroes need not apply," despite being recognizably darkskinned persons of African descent. ${ }^{24}$

Indeed, West Indians were able to get jobs in several lines of work that had previously either been reserved for "whites only" or had been segregated - including porters, elevator operators, nursing aides and so

${ }^{17} I d$.

${ }^{18} \mathrm{Id}$. at 121 (describing the concentration of West Indians in formerly White middle-class neighborhoods).

19 IRMa WatKInS-OwENS, BloOd RELATIONS: CARIBBEAN IMMigRANTS AND THE HARLEM COMmunity, 1900-1930, at 46 (1996) (discussing the heavy representation of West Indians among black realtors).

${ }^{20}$ See Vilna Francine Bashi, SuRvival of the KnitTED: IMmigrant Social NeTwORKS IN A STRATIFIED WORLD 182-206 (2007).

${ }^{21}$ Malcolm Gladwell, Black Like Them, NEW YORKER, Apr. 29, 1996, at 74, 78. ). Gladwell also discusses long-standing tensions between African Americans and his Jamaican co-ethnics (borne partly from differential treatment by employers.

${ }^{22} I d$.

${ }^{23}$ Id.; see also LeIGH DAVID BENIN, THE NEW LABOR RADICALISM AND NEW YORK CITY'S GARMENT INDUSTRY: PROGRESSIVE LABOR INSURGENTS IN THE 1960S (Stuart Bruchey, ed. 2000); Herbert Hill, The Untold Story, THE CRISIS (November 1962); Robert Laurentz, Racial/Ethnic Conflict in New York City Garment Industry 1933-1980 (Ph. D. dissertation, State University of New York at Binghampton 1980).

${ }^{24} I d$., This point is made by prominent Harlem Renaissance intellectual, W.A. Domingo in W.A. Domingo, The Tropics in New York, SURVEY GRAPHIC, Mar. 1925, at 648, 649 available at http://www.unz.org/Pub/TheSurvey-1925mar01; W. A. Domingo, Gift of the Black Tropics, in Alain Locke, ED., The New Negro: An InTERPRETATIOn (1925)). See also Dennis Forsythe, Black Immigrants and the American Ethos: Theories and Observations, in CARIBBEAN IMMigRATION TO THE United STATES 55, 65-66 (Roy S. Bryce Laporte \& Delores M. Mortimer eds., 1983) (same). 
forth. ${ }^{25}$ Thus one might say that West Indians were at the forefront of the defacto (if not de jure) "integration" of the workplace in 1920s New York, long before comprehensive legislation existed to preclude racial discrimination in employment. ${ }^{26}$

This is a book about property and yet I have begun with a narrative about work. Why? There are significant analogies between West Indian trajectories of upward advancement in both areas. To understand the analogies one might consider Richard Brooks and Carol Rose's book Saving the Neighborhood. ${ }^{27}$ It tracks the trajectory and persistence of racially restrictive covenants, that is, restrictions barring racial and ethnic groups from owning real property in particular neighborhoods. Such covenants were applied with particular force against certain racial, ethnic and religious groups in the pre-civil rights era. ${ }^{28}$ Drawing on the law and social norms literature, their thesis is that the persistence of these covenants even after their enforcement was outlawed by the Supreme Court was less about their enforceability than about their value in "signalling" norms of racial exclusivity. ${ }^{29}$

The connection between Brooks and Rose's narrative and Gladwell's Jamaican garment workers is implicit. A workplace sign saying "Negroes need not apply," is the employment equivalent of a racially restrictive covenant. If we argue by analogy to Brooks and Rose, these workplace signs have a signalling value in employment, just as racially restrictive covenants do in property. The narratives of 1920s West Indian New Yorkers indicate that while racial discrimination was rife with the accompanied signalling ("Negroes need not apply; this property may not be sold to Negroes"), these exclusions were not being consistently applied to West Indians in both the domains of employment and property. The question becomes what was so special about West Indians?

In this Essay, I offer an entirely new narrative that is outside the traditional civil rights discourse. The traditional comparative approach to the study of the effects of institutional barriers to housing would entail the following steps. First, comparative scholars consider two groups of people who are ostensibly similar (namely, African Americans and West Indians, both groups being "black"). Second, they observe different outcomes (namely, West Indians occupying better housing than African Americans).

\footnotetext{
${ }^{25}$ This point is made by references in the previous footnote.

${ }^{26}$ One might also see the work of Winston James, on the black radicals of the Harlem Renaissance who were disproportionately West Indian. Many of these radicals were involved in the labor struggles of early $20^{\text {th }}$ Century New York City. See generally, Chapters 5 and 6 of Winston

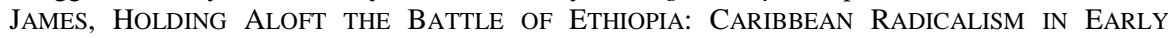
Twentieth Century America (1998). Chapter 5 of Joyce Moore Turner, CaribBean CRUSADERS AND THE HARLEM RENAISSANCE (2005) is also helpful. The most comprehensive treatment is actually BRUCE NELSON, Divided We STAND: AMERICAN WORKERS AND THE STRUGGLE FOR BLACK EQUALITY (2002). Chapter 2 is particularly helpful.

${ }^{27}$ Richard R.W. Brooks \& CARol M. Rose, SAVING the NEIGHborhood: Racially RESTRICTIVE COVENANTS, LAW, AND SOCIAL NORMS (2013).

${ }^{28} I d$.

${ }^{29} I d$.
} 
Third, they consider how discriminatory frameworks operate differently with respect to the two groups of people.

This Essay takes a different approach. In fact, it is unclear to me that West Indians are necessarily an appropriate comparative group. In Part I, in a brief background to the larger argument, I address a few of the theories that have been prominent in the civil rights literature. These theories might be classified in the tradition of the prominent sociologist Goffman as "performative." ${ }^{30}$ The central idea that performative theories share is that particular groups (in this case, West Indians) are better at "performing" so as to assuage stereotypical (white) fears (about blacks), and these "performances" have tangible benefits in several arenas including housing. ${ }^{31}$

In Part II, I transition to my alternative argument. I note that in the early decades of the $20^{\text {th }}$ Century when West Indians started arriving in New York, homeowners were almost entirely white elites. Blacks (although their numbers were miniscule) and poorer whites were essentially excluded from home-ownership. Relying on the work of other scholars, I note that racial segregation in real property ownership (and the associated racial covenants) may be conceived as a racial monopoly in which racial cartels appropriate anti-competitive techniques to monopolize access to real property. ${ }^{32}$

In Part II, I also note that maintaining racial exclusivity in certain neighborhoods was dependent on white owners maintaining a united front, that is, they must uniformly refuse to sell. ${ }^{33}$ West Indian realtors were expert at finding defectors, namely, whites willing to break norms of racial exclusivity, in exchange for their ability to extract a premium for selling to blacks early. Thus, West Indian brokers then proceeded to buy significant numbers of titles, which were then off-loaded to fellow West Indians. West Indian realtors could act in confidence because they were often buying in trust (de-facto if not de-jure) for fellow West Indians. ${ }^{34} \mathrm{I}$ also note that arguably West Indian realtors were engaged in "blockbusting." ${ }^{35}$ Decades later, during the civil rights era, blockbusting gained notoriety as the deliberate promotion of "racial tipping" in previously all-white or integrated neighborhoods for speedy transition to black neighborhoods by realtors and other real estate players seeking quick financial gain. ${ }^{36} \mathrm{I}$ contend that early West Indian realtors, appropriated techniques that arguably approximated blockbusting and preceded their mid-century peers by decades. ${ }^{37}$

\footnotetext{
${ }^{30}$ Theories of "passing" and "covering" are peformative theories. The oft-cited definition of covering comes from Erving Goffman's classic, STIGMA: NOTES ON THE MANAGEMENT OF SPOILED IDENTITY (1986) namely trying to rendering a characteristic invisible. The term has been more recently popularized again in Kenji Yoshino's COVERING: THE HIDDEN ASSAULT ON OUR CIVIL RIGHTS (2006).

${ }^{31}$ See infra Part I.

${ }^{32} I d$.

${ }^{33}$ See infra Part II.

${ }^{34} \mathrm{Id}$.

${ }^{35} \mathrm{Id}$.

${ }^{36} I d$.

${ }^{37}$ See infra Part I.
} 
In Part III, I transition to the history that "previews" this period in New York in the British West Indian islands from which West Indian migrants originate. ${ }^{38}$ I note that there are repeated instances of West Indians "busting" white monopolies in land-ownership, throughout the West Indian colonies in contravention of racial norms in the British colonies of who was allowed to own land where. Upon arrival in New York, West Indians encountered another (albeit different) racial monopoly in real property ownership, namely Northern racial segregation. They essentially appropriated the same techniques that they had utilized in the West Indies to break into white neighbourhoods. ${ }^{39}$

In Part III, I also apply Hirschman's classic framework of "voice," "exit," and "loyalty." I note that in the aftermath of Emancipation in the British West Indies, when given a "choice" to remain on sugar plantations (in sharecropping relationships that many West Indian freedmen believed too closely approximated slavery), freedmen overwhelmingly chose "exit." But West Indian freedmen were able to exit only because they had land to exit to. At this point, I re-introduce the thesis on busting racial monopolies. West Indian land ownership was facilitated in part by white "defectors," that is, white land-owners who deviated from norms of racial exclusivity and "cashed out" by selling their plantations to black people.

West Indian blacks were not passive players in this process. Several plantation owners were "converted" by a savvy black land-brokering class, who created reserves of cash for land purchase by pooling the resources of their clients. That is, land brokers acted as trustees of cash deposits for multiple prospective purchasers, while cultivating cash-strapped members of the plantocracy. When planters were ready to sell, they pounced and paid cash up-front.

In Conclusion, I note that there are also traces (but only traces) of the legal transplant literature. This historical practice of activity in the land markets in the West Indies has long-term legal consequences in the United States. This is an unconventional legal transplant argument as I have no formal law to substantiate the argument.

But rules matter, even if they are only norms and not embodied in formal law. The efficiency of black West Indians in acquiring property in their islands of origin was undergirded by a set of rules, namely rules that solved collective action problems by allowing land brokers to buy land in trust on behalf of other West Indians. These rules also protected future landowners from unscrupulous trustees. Brokers had significant opportunities for opportunistic behavior. Yet, they rarely ran off with the money of their fellow West Indians because such behavior would have entailed communal expulsion. Similar patterns are replicated when they arrived in New York City.

Admittedly, the legal-transplant literature is not a perfect fit. For example, that there is not much in the way of "law," namely, state-backed

${ }^{38}$ See infra Part III.

${ }^{39}$ Id. 
rules, that were formally transplanted from the West Indian context to New York. Nevertheless, West Indians brought with them a robust set of norms which governed how they operated in housing and land markets. One might think of West Indians as comparable to diaspora ethnic minorities such as the Chinese in Indonesia, Philippines, and Malaysia, or the Maghribi Jews in the "Muslim West" who traded across borders with informal rules in complex capital markets long before the development of formal commercial law, either domestically or transnationally.

\section{PERformative THEORIES}

The narratives of 1920s West Indian New Yorkers indicate that while racial discrimination was rife with the accompanied signalling ("Negroes need not apply; this property may not be sold to Negroes"), these exclusions were not being consistently applied to West Indians in both the domains of employment and property. ${ }^{40}$ Take, for example, sections of upscale Harlem that were understood to be "all white." ${ }^{41}$ Much to the surprise of leading journalistic observers, moderately affluent West Indians were permitted to live alongside whites, albeit in small numbers. ${ }^{42}$

This occurred even as the exclusions, and particularly racial covenants, were legally enforceable; indeed, racially restrictive covenants were widespread in Harlem at the time. ${ }^{43}$ At least with respect to these quasiaffluent West Indians, racially restrictive covenants appear to have been sometimes ignored. ${ }^{44}$ What was so special about West Indians?

There are a number of factors that might account for this disparate (and advantageous) treatment of West Indians in relation to other blacks. Indeed, a skeptical reader might wonder: why is this phenomenon so special?

Notably, West Indians were not atypical in this respect. For example, another group that was often the target of racially restrictive covenants was Jews. ${ }^{45}$ Yet Jews were often purchasing property even when covenants clearly stated that property may not be sold to members of the "Hebrew race." 46

Racial covenants which purported to constrain purchases by members of the "Hebrew race" were widespread well beyond the 1950 s. ${ }^{47}$ Indeed it is clear that discrimination more generally against persons of Jewish heritage

\footnotetext{
${ }^{40}$ See infra Part II.

${ }^{41} \mathrm{Id}$.

${ }^{42} I d$.

${ }^{43}$ Kevin Fox Gotham, Urban Space, Restrictive Covenants and the Origins of Racial Residential Segregation in a US City, 1900-50, 24.3 INT'L J. OF URB. \& REG'L RESEARCH (2000), available at http://tulane.edu/liberal-arts/upload/RestrCovenants.pdf ; GILBERT OSOFSKY, HARLEM: THE MAKING OF A GHETTO: NEGRO NEW YORK 1890-1930 (1971).

${ }^{44}$ See infra Part II.

${ }^{45}$ BROOKS \& ROSE, supra note 27.

${ }^{46} I d$.

${ }^{47} I d$.
} 
was still rife (in employment, schooling and property markets, for example).$^{48}$ Yet, simultaneously there is evidence that many early Jewish families overcame these barriers.

Jews who bought properties in spite of discriminatory covenants essentially did so by what Dershowitz would deem "passing." Dershowitz is critical of those who mask their underlying Jewish identity, particularly Jewish migrants and their descendants in the United States, which he deems to be the most favourable environment in which Jews have settled as a minority (leaving Israel aside, where Jews constitute a majority).$^{49}$ However, it seems unfair to label a failure to mention religious heritage when conducting property-related transactions as "passing," since religious heritage could hardly be relevant to property transactions. Why mention what is not relevant?

Irrespective of what one thinks of "passing," the typical West Indian conducting a property-related transaction (in contravention of a racial covenant), would have been different than someone of Jewish heritage conducting a similar transaction (again, in contravention of a discriminatory covenant.) Typically, these West Indians were not "passing." 50 Notably, many of these West Indians (even affluent ones) had no such "opt-out" option. Most West Indians were clearly phenotypically black ${ }^{51}$ and as such were clearly "outsiders." That is, as blacks, West Indians were clearly among the targets for whom the aforementioned Brooks/Rose "signals" were intended.

Although "passing" may not explain the West Indian presence in white neighbourhoods, Yoshino's work in the gay civil rights scholarship, reminds us that "passing" has a close cousin, namely, "covering." 52 That is, even if West Indians did not have the option of passing (i.e. masking their

\footnotetext{
${ }^{48} I d$.

${ }^{49}$ Here, I depend on Kenji Yoshino's distinction between passing and covering. Kenji Yoshino has popularized the word "covering." See Yoshino, supra note 30; Kenji Yoshino, Covering, 111 YALE L.J. 769 (2002). While "covering" is a complex concept, a more indelicate term for "covering" (at least as used in this context) is "passing." That is, Jewish families would fail to mention that they were Jewish (and thus by implication "pass" as Christians). Consider, for example, Lisa Bonos' discussion of Jewish families who "passed" to fit into overwhelmingly Christian largely Southern Baptist communities that had historically been hostile to Jews, in her review of Theodore Ross' AM I A Jew: Lost Tribes, LAPSED Jews AND One MAN's SEARCh fOR Himself (2012). See Lisa Bonos, Op-Ed., "Am I a Jew: Lost Tribes, Lapsed Jews and One Man's Search for Himself", WASH. POST., Nov. 2, 2012, http://www.washingtonpost.com/opinions/am-i-a-jew-lost-tribeslapsed-jews-and-one-mans-search-for-himsel-by-theodore-ross/2012/11/02/864c9fa0-07de-11e2858a-5311df86ab04_story.html. Although such historical practices were undoubtedly critical to negotiate life in deeply anti-Semitic societies, Dershowitz for example, is disapproving of Jews who "pass." Alan M. Dershowitz, The Vanishing American Jew: In SEarch OF Jewish IDENTITY FOR THE NEXT CENTURY (1997),

${ }^{50}$ The black Barbadian migrant, Solomon Riley, known as Millionaire Riley, discussed below, who is known to have bought properties in the name of his white wife would be an exception. Yet even Riley's tactic of "passing" could only have been effective in his earliest transactions. After this, he became widely known (and hated) for moving blacks into previously "white" properties - so presumably the tactic of hiding behind his wife would no longer have been effective.

${ }^{51}$ James, Explaining Afro-Caribbean Social Mobility, supra note 3.

${ }^{52}$ Yoshino, supra note 49.
} 
underlying identity), they may nevertheless have been "covering." Those who engage in "covering" retain and disclose the underlying identity, "but make it easy for others to disattend." 53

In an arguably related argument in "Working Identity," Carbado and Gulati assert that many racial minorities "proactively work their identity to avoid discrimination in the first place." 54 Notably, blacks "work" their identities to negotiate inter-group discrimination (for example, landlords or employers preferring whites over blacks). As importantly, they "work" their identities to negotiate intra-group discrimination (that is landlords or employers preferring some black people over other black people).

We have long known that there are elements of identity that might be classified in the tradition of the social theorists, Goffman and Butler as "performative." The notion that some West Indian blacks "work" their identities to their benefit (and by extension to exclusion of other blacks, namely, native African Americans) is a quintessentially performative theory. ${ }^{55}$ Dershowitz was making essentially an equivalent point with respect to "passing" Jews.

Moreover, long before it surfaced in the civil rights scholarship, this point was made (with pointed candor) in real life. West Indians were well known for emphasizing that they were "British subjects" - a phenomenon that has been referred to as "performing Britishness." ${ }^{56}$ A. Phillip Randolph, the civil rights leader chastised West Indians for retaining their status as British subjects, as opposed to naturalizing to American citizenship. ${ }^{57}$ Randolph's point was implicit: West Indians were abusing the good graces of Americans by choosing to retain their status as British subjects, even as they enjoyed the benefits of long-term American residency, without taking on the requisite obligations of American citizenship (including civil rights activism).

That is, Randolph felt that West Indians believed that they were better off as "British subjects" rather than as "colored" Americans. One could hardly find a better real-life example of a group being accused of performative identity. The question seems clear: were West Indians beneficiaries of "covering" or "working" their identities in housing as well?

All of these paths lead to one question: how did West Indians become "insiders," that is, to occupy some status sufficiently different than the conventional "outsider" status, to render them eligible (even informally) for housing, traditionally denied to persons of African descent? This is the puzzle that this essay seeks to engage. Something seems not to add up ...

\footnotetext{
${ }^{53} I d$.

${ }^{54}$ Devon W. Carbado \& Mitu Gulati, Working Identity, 85 CoRnell L. Rev. 1259 (2000).

${ }^{55}$ Performative theories are now most prominently associated with Goffman and Butler. ERVING Goffman, The Presentation of Self in Everyday Life (1959); Judith Butler, Gender TROUBLE: FEMINISM AND THE SUBVERSION OF IDENTITY (1990).

${ }^{56}$ Eleanor Brown, How the US Selected for a Black Bourgeosie Geo. Imm. L. J.

57 See Daryl Scott, "Immigrant Indigestion” A Philip Randolph: Radical and Restrictionist, CTR. FOR IMMIGRATION STUD. (June 1999), http://cis.org/AfricanAmericanAttitudesImmigrationAphilipRandolph.
} 


\section{HOW WEST INDIANS CAME TO BUY INTO WHITE NEIGHBORHOODS}

\section{A. Prelude 1900-1920}

How did West Indians come to enter white neighborhoods in the first place? West Indians starting arriving in New York in significant numbers in the early 1900s. ${ }^{58}$ The early narratives of West Indian migrant life in New York, as told by the earliest migrants, indicate that they did not initially meet with significant resistance..$^{59}$ Indeed some early West Indian migrants moved into white neighborhoods. ${ }^{60}$

According to Massey and Denton's classic on residential segregation, American Apartheid, segregation was hardly an issue, in most modern cities, including New York prior to the early 1900s. ${ }^{61}$ The West Indian experience upon arrival in New York dovetails well with Massey and Denton's historical narrative.

It bears emphasis that at the time that West Indians starting arriving in New York, the black population was miniscule (less than $3 \%$ ). ${ }^{62}$ At the turn of the century, the number of West Indians (and indeed the number of African-Americans) would have been too small to occasion notice. ${ }^{63}$ It was only when blacks start arriving in Northern cities in large numbers that the institutional forces that we typically associate with segregation began to arise. ${ }^{64}$ These institutional forces included race-based steering by realtors, race-based residential advertising, and so forth. ${ }^{65}$

\section{B. 1920 onwards: Racial cartelization}

In the period immediately preceding 1920 , there was a dramatic increase in the number of blacks in New York City, occasionally by a burst of migration of West Indians, as well as African-American migrants from the South. ${ }^{66}$ Although blockbusting, as an institutional force which

\footnotetext{
${ }^{58}$ James, Explaining Afro-Caribbean Social Mobility, supra note 3.

${ }^{59}$ WATKINS-OWENS, supra note 19.

${ }^{60} \mathrm{Id}$.

${ }^{61}$ See, e.g., Douglas S. MASSEy \& NANCy A. Denton, American APARTHeID: SEgREgation AND THE MAKING OF THE UNDERCLASS (Cambridge 1993) ("There was a time, before 1900, when .. . blacks were more likely to share a neighborhood with whites than with other blacks.")

${ }^{62}$ Mary White Ovington, Half A Man: The Status of the Negro in New York (1911); W.E.B. Dubois ON SOCIOLOGY AND THE BLACK COMMUNITY 140-54 (Dan S. Green \& Edwin D. Driver, eds. 1980); see also James, Explaining Afro American Social Mobility, supra note 3; ISABEL WILKERSON, THE WARMTH OF OTHER SUNS: THE EPIC STORY OF AMERICA'S GREAT MIGRATION (2011); WALLACE THURMAN, NEGRO LIFE IN NEW YORK'S HARLEM (1928).

${ }^{63}$ James, Explaining Afro American Social Mobility, supra note 3.

${ }^{64}$ MASSEY \& DENTON, supra note 61.

${ }^{65} \mathrm{Id}$.

${ }^{66}$ Osofsky, supra note 43.
} 
accelerates segregation, ${ }^{67}$ has been out of vogue as an academic topic for decades, it clearly featured prominently in New York City. Indeed, blockbusting appears to have been taking place in New York as early as the 1920s. ${ }^{68}$

By way of background, blockbusting is the deliberate facilitation of "racial tipping" in previously all-white or integrated neighborhoods for speedy transition to black neighborhoods. Such "tipping" is typically facilitated by realtors (and other actors in the real estate industry) bent on eliciting super-commissions. ${ }^{69}$ Notably, blockbusting is an academic term of much later heritage than 1920s New York; blockbusting only emerges as a phenomenon in literature in the 1950s.$^{70}$ However, in this section, I argue that the actions of early West Indian realtors provided a preview of blockbusting. Indeed, they appropriated techniques that arguably approximated blockbusting and preceded their mid-century peers by decades. $^{71}$

Black realtors seeking to open up more housing to their black clients (while simultaneously making commissions), were up against significant institutional forces. For example, Massey and Denton discuss how "voluntary associations" of white citizens in Northern cities (as opposed to the South, which we more typically associate with institutionalized segregation) were extraordinarily vigilant in ensuring that their neighborhoods remained "whites only."72 Every effort was made to prevent blacks from entering certain neighborhoods, including threatened boycotts of white real estate agents who cooperated with black agents, and the withdrawal of support from white businesses that served black customers. ${ }^{73}$ Others went as far as "collect[ing] money to create funds to buy property from black settlers or to purchase homes that remained vacant for too long; [and] offer[ing] cash bonuses to black renters who agreed to leave the neighborhood."74

Massey and Denton's classic is typically where scholars of segregation start. ${ }^{75}$ However, Massey and Denton are writing primarily of the 1950s and later decades. Moreover, they do not discuss New York in the

${ }^{67}$ It bears emphasis: blockbusting is a term of much later heritage (circa 1950s). See Dmitri Melhorn, A Requiem for Blockbusting: Law, Economics, and Race-Based Real Estate Speculation, 67 FORDHAM L. REV. 1145 (1998).

${ }^{68}$ See New York Times articles, infra note 170.

${ }^{69}$ Blockbusting came to widespread public attention through a widely read article in the Saturday Evening Post. Following the public outcry that accompanied this article, there were a range of federal, state and municipal initiatives to prevent blockbusting. Norris Vitchek, Confessions of a Block-Buster, SATURDAY EVENING POST, July 14, 1962.

${ }^{70}$ MASSEY \& DENTON, supra note 61.

${ }^{71}$ Given Melhorn's broader view of the important market roles played by blockbusters in opening up new housing to blacks, one might anticipate a similarly charitable assessment of their West Indian counterparts. See MELHORN, supra note 67.

${ }^{72}$ MASSEY \& DENTON, supra note 61.

${ }^{73} \mathrm{Id}$.

${ }^{74} I d$.

${ }^{75} I d$. 
detail that they do Chicago. ${ }^{76}$ Osofky's classic study of the development of Harlem is helpful in this regard. ${ }^{77}$ While to modern minds, Harlem is known as an iconic black community (the "capital of black America"), it was originally white. ${ }^{78}$ Moreover, it was one of the first communities in which West Indians settled. ${ }^{79}$ Osofky makes clear that the techniques discussed by Massey and Denton in mid-century Chicago, were also utilized by whites in Harlem to discourage black settlement. ${ }^{80}$ Moreover, they were utilized as early as the 1920 s. $^{81}$

Viewing racial segregation in real property ownership through the lens of the antitrust literature," Roithmayr deems white neighbourhood associations "racial cartels." 82 What is a racial cartel $?^{83}$ Cooter analogizes racial cartels to conventional cartels noting that "[j] ust as producers collude to fix prices and obtain monopoly profits, so [racial cartels] collude to obtain the advantages of a monopoly control over markets." 84

One such market is the real estate market. Appropriating Cooter's terminology, Roithmayr argues that a segregated residential community is a classic example of a racial monopoly. ${ }^{85}$ Alongside homeowner's associations, Roithmayr argues that real estate boards, as well as collectives of white real estate agents, were quintessential examples of "cartel"-type organizations. ${ }^{86}$

These organizations played a critical role in policing racial covenants, typically noted on deeds, which prevented white homeowners from selling to blacks. And it bears emphasizing that racial covenants were perhaps the most genial of many pernicious methods utilized to exclude blacks. In New York, as in Chicago, such techniques included boycotts of white real estate agents who cooperated with black real estate agents.

Racial covenants were of course, classic tools of anti-competitive behavior - they served an important role in curtailing black access to property in certain neighbourhoods. If the neighbourhood associations discussed by Denton and Massey in mid-century Chicago were racial cartels, there is little doubt that similar associations in Harlem in the 1920s merit a similar label.

${ }^{76} I d$.

${ }^{77}$ OSOFSKY, supra note 43 (exploring the history of the black community of New York City in the late 19 th and early $20^{\text {th }}$ Centuries).

${ }^{78}$ E. Franklin Frazier, Negro Harlem: An Ecological Study, AMERICAN JOURNAL OF SOCIOLOGY el

${ }^{79}$ OSOFSKY, supra note 43; see also New York Times articles, infra note 170.

${ }^{80}$ OSOFSKY, supra note 43.

${ }^{81} \mathrm{Id}$.

82 Daria Roithmayr, Racial Cartels, 16 Mich. J. RACE \& L. 45 (2010).

${ }^{83} \mathrm{Id}$.

${ }^{84}$ Robert Cooter, Market Affirmative Action, 31 SAN DIEGo L. REV. 133, 150 (1994) ("Just as producers collude to fix prices and obtain monopoly profits, so [racial cartels] collude to obtain the advantages of a monopoly control over markets").

${ }^{85}$ Daria Roithmayr, Barriers to Entry: A Market Lock-in Model of Discrimination, 86 VA. L. REV. 727 (2000) [hereinafter Roithmayer, Barriers to Entry"] (arguing that market lock-in supplies the argument of market failure).

${ }^{86}$ Roithmayr, Racial Cartels, supra note 83. 
Roithmayr goes further arguing that "early neighbourhood advantage" secured by racial cartels, has now become "locked-in." 87 Utilizing analogies from the antitrust literature, she notes if a firm's anticompetitive conduct occurs early enough in the development of an industry, this conduct may provide the firm with such a significant advantage that other competitors find it virtually impossible to catch up. ${ }^{88}$ In other words, "the 'early-mover' advantage . . . can become self-reinforcing over time" so much so that economists refer to the early mover advantage as being "lockedin." ${ }^{89}$ For example, Microsoft's oft-cited success with the Windows operating system (to the exclusion of other operating systems) illustrates a classic example of institutional "lock in." 90

Similarly, Roithmayr argues that early neighbourhood advantage becomes "locked in" through "self-reinforcing neighbourhood effects." 91 These include job-referral networks (which are heavily neighbourhoodbased) and mechanisms of financing public schools (in which better off neighborhoods receive better public financing given their deeper property tax base). ${ }^{92}$ Even if the language of antitrust seems strange when utilized in this context, the sociological literature provides significant support for Roithmayr's thesis. If Roithmayr is right, whether or not blacks are successful in "breaking" racial cartels early may have long-term implications for whether they access critical networks needed to improve their economic prospects.

Hence the assumption which is implicit in the literature (namely that West Indians and African Americans were in the same boat with respect to residential segregation in New York) needs to be called into question. While there may have been early institutional similarities with respect to how residential segregation operated against West Indians and African Americans, the institutional differences are potentially significant. The early clue of a critical difference between the two groups is what the sociological literature clearly substantiates - namely that West Indians were able to access owner-occupied middle class white neighborhoods, earlier and in larger numbers.

Indeed, if we follow through the implications of Roithmayr's thesis, the critical difference between early African-American migrants and early West Indian migrants to New York City may be the extent to which early racial cartels in housing constrain their long-term opportunity sets. Thus, while institutional exclusion may have been "locked in" in relation to African Americans, this may not be true (or may be less true) of West Indian Americans. My thesis is that West Indian Americans were at least partially

${ }^{87}$ Daria Roithmayr, Locked in Segregation, 12 VA. J. SOC. POL'Y \& L. 197 (2004).

${ }^{88} I d$ at 202.

${ }^{89} \mathrm{Id}$.

${ }^{90}$ Roithmayr, Locked in Segregation, supra note 88 at 202, 206.

${ }^{91}$ Roithmayr, Locked in Segregation, supra note 88.

${ }^{92} \mathrm{Id}$. 
successful in busting the racial cartels which characterized segregated neighborhoods - the subject of the next section.

\section{White defection}

The long-term success of any cartel is at least partly dependent on its ability to prevent defection among its members. ${ }^{93}$ To prevent defection, cartel members typically threaten each other with severe retaliation. ${ }^{94}$ Moreover, the threats have to be not only severe, they also have to be credible. ${ }^{95}$ Thus, it is unsurprising that the primary techniques (detailed by Denton and Massey and later deployed by Roithmayr to support her racial monopoly model) are focused on the prevention of white defection. ${ }^{96}$

If the prevailing norm was one of racial exclusivity in housing, the key was to prevent whites from deviating from this norm. ${ }^{97}$ If they did not sell, there would be no homes for blacks to buy. White voluntary associations realized that the key to keeping neighborhoods all white was pinpointing whites who were at risk of defection.

Thus, it is not coincidental that a series of articles in the New York Times (contemporaneous with the initial black entries into white neighborhoods) discuss efforts to publicly "shame" whites who sold property to blacks, and intermediaries involved in the transactions (such as white real estate agents) -- not unlike the methods detailed in the Massey and Denton extract above. ${ }^{98}$ The point was clearly to drive home that the costs of defection (including but not limited to reputational costs), would be significant. One can hardly imagine that it was good for business to be publicly shamed.

A return to Brooks and Rose is in order. Brooks and Rose begin the book by underlining the persistence of such covenants well into the second half of the twentieth century. ${ }^{99}$ One need only consider the deeply controversial revelation during Justice Rehnquist's nomination hearings (for the position of Chief Justice) that he held property with a racially restrictive covenant, ${ }^{100}$ long after Shelly v. Kraemer, the landmark case that held that such covenants were unenforceable. ${ }^{101}$ Brooks and Rose address the puzzle of the persistence of such covenants, even after Shelly $v$. Kraemer ${ }^{102}$

\footnotetext{
${ }^{93}$ Gellhorn ET AL., ANTITRUST LAW AND ECONOMiCS IN A NutShell 192-200 (5 th $\left.^{\text {ed. }} 2004\right)$ : Einer Elhauge, United States ANTitrust LaW AND ECONOMics (2011); Keith Hylton; ANTITRUST LAW: ECONOMIC THEORY AND COMMON LAW EVOLUTION (2003).

${ }^{94} I d$.

${ }^{95} I d$.

${ }^{96}$ DENTON \& MASSEY, supra note 61; Roithmayr, Locked in Segregation, supra note 88.

${ }^{97}$ Roithmayr, Locked in Segregation, supra note 88.

${ }^{98}$ See New York Times Articles, infra note 170.

${ }^{99}$ BROOKS \& ROSE, supra note 27.

${ }^{100} I d$.

${ }^{101}$ Shelly v. Kraemer, 334 U.S. 1 (1948).

${ }^{102}$ BROOKS \& ROSE, supra note 27.
} 
Drawing on the law and social norms literature, their thesis is that the existence of such covenants is less about their enforceability than about their value in "signalling" norms. ${ }^{103}$ These covenants signal to racial "insiders" that they can rest assured that only fellow insiders are welcome in the neighborhood. ${ }^{104}$ Similarly, they signal to outsiders that they need not apply. ${ }^{105}$ The mere "signal" had significant value in accomplishing policy goals that may now seem anachronistic such as the preservation of property values (even at the significant cost of black exclusion) and the reduction in social tension (which was thought to be more likely if blacks and whites were not living together). ${ }^{106}$

Potential defectors should typically conduct a cost-benefit analysis: will I gain more from the short-term defection than I gain from long-term participation in the cartel $?^{107}$ Thus, the key to eliciting defection from the aforementioned norms is to raise the benefits from short-term defection. A prospective seller who believes that she can get cash (a lot of it, and up front) will perhaps convince herself that she can move into a nicer neighborhood.

For this reason, it is unsurprising that accounts of the time accuse both white agents (and by extension black agents acting in concert with them) of taking advantage of an atmosphere of racial panic to make extraordinary commissions for themselves. ${ }^{108}$ The returns for their clients (certainly the earliest defectors) would have had to have been similarly impressive. This would be particularly true in relation to whites who sold later and presumably for less, given that the entry of blacks typically lowered real estate values. ${ }^{109}$

There are of course, at least two ways of looking at this: one could characterize a West Indian broker (acting in concert with a white broker, since blacks could not represent whites) as taking "advantage" of "racial panic." Or one could simply look at it as West Indian realtors expanding market access for their clients who were facing a paltry, substandard, and overpriced "black" housing stock.

But, the fact remains that irrespective of the moral lens through which one views such transactions, no West Indian broker would be in a position to take advantage of "racial panic" without cash. West Indians were well placed to elicit defections because they had cash. I believe that my claim is a modest one. What distinguished West Indians from their peers in the black realtor sector (and from African Americans more generally) was that they had cash; ${ }^{110}$ they dominated the black realtor sector because they stood

\footnotetext{
${ }^{103} I d$.

${ }^{104} I d$.

${ }^{105} I d$.

${ }^{106} I d$.

${ }^{107}$ See GeLLHORN, supra note 93.

${ }^{108}$ See infra note 170.

109 This is well explained in MELHORN, supra note 67.

${ }^{110}$ See Calvin Holder, Making Ends Meet: West Indian Economic Adjustment in New York City, 1900-1952, 1 WADABAGEI 31, 55-60 (1998) (documenting West Indian representation among realtors, credit providers for home purchase, and insurance companies).
} 
out for their relatively liquidity (and for the liquidity of their clients). ${ }^{111}$ Cash-rich blacks were still virtually unheard of at the time. ${ }^{12}$

This is why I believe that my claim is modest - West Indians were able to elicit defections, simply because they had cash. Notably, they had cash because they arrived from the West Indies having long been owners of real-property in their home countries. ${ }^{113}$ Also importantly, they had cash because binding rules undergirded their transactions and rules facilitated the availability of liquidity. ${ }^{114}$

West Indians buyers were more likely to be able to access informal credit that allowed them to generate cash when needed. ${ }^{115}$ That is, even when they did not have immediate cash, they had access to informal mortgage financing. ${ }^{116} \mathrm{~A}$ seller should be indifferent if a buyer needs a mortgage, as long as the mortgage closes sufficiently quickly to produce cash in short order. Notably, West Indians had such access to mortgage financing (first

${ }^{111}$ For a description of the liquidity of West Indian players in real estate, see Eleanor Brown, The Blacks Who "Got Their Forty Acres": A Theory of Black West Indian Migrant Asset Acquisition, 89 N.Y.U. L. REV. $27,50$.

112 There is a plethora of writing on the institutional challenges to building net-worth among African Americans, both historically and in contemporary times. For summaries of statistical comparative net worth data between blacks and whites, particularly in the aftermath of the 2009 crisis, please see Paul Taylor et al., Pew Research Center, Wealth Gaps Rise to ReCord Highs Between WHITES, BLACKS, HISPANICS 1 (2011), available at http://www.pewsocialtrends.org/2011/07/26/wealth-gaps-rise-to-record-highs-between-whitesblacks-hispanics/; see also Thomas M. Shapiro et al., The Racial Wealth Gap Increases Fourfold, Brandeis Univ., InSt. ON Assets \& Soc. Policy, Research AND POlicy Brief (2010); WiLhElmina LeIGH ET AL., Asset Building in Low-Income Communities of Color: Predisposing Factors and Promising Practices in States Effective at Building Assets for Low Income Residents, JOINT CTR. FOR POL. \& ECON. STUD. (2009). The most comprehensive article addressing historical barriers to land ownership particularly in the Jim Crow South (with clear implications for later real property ownership in the North) is by Thomas W. Mitchell, From Reconstruction to Deconstruction: Undermining Black Landownership, Political Independence, and Community Through Partition Sales of Tenancies in Common, 95 Nw. U. L. REV. 505, 517-23 (2001). Other articles in the legal scholarship in this area include, e.g., Ellen D. Katz, African-American Freedom in Antebellum Cumberland County, Virginia, 70 CHI.-Kent L. REV. 927 (1995); Thomas W. Mitchell, Destabilizing the Normalization of Rural Black Land Loss: A Critical Role for Legal Empiricism, 2005 WIS. L. REV. 557 (2005); Thomas W. Mitchell et al., Forced Sale Risk: Class, Race, and the "Double Discount", 37 FlA. ST. U. L. REV. 589 (2010). Articles addressing the asset acquisition implications of more recent discrimination include Michael S. Barr, Credit Where It Counts: The Community Reinvestment Act and Its Critics, 80 N.Y.U. L. REV. 513 (2005); Anthony J. Taibi, Racial Justice in the Age of the Global Economy, 44 DuKE L.J. 928 (1995); A. Brooke Overby, The Community Reinvestment Act Reconsidered, 143 U. PA. L. REV. 1431 (1995); Keith N. Hylton \& Vincent D. Rougeau, Lending Discrimination: Economic Theory, Econometric Evidence, and the Community Reinvestment Act, 85 GEO. L.J. 237 (1996); Rashmi Dyal-Chand, Useless Property, 32 CARDOZO L. REV. 1369 (2011). Other articles outside the legal scholarship include THE BLACK RURAL LANDOWNER-ENDANGERED SPECIES (Leo McGee \& Robert Boone eds., 1979); see also Mark R. Schulte, The Dream Realized?: African American Landownership in Central Georgia Between Reconstruction and World War Two, 72 AGRIC. HIST. 298, 307 (1998).

${ }^{113}$ See Brown, supra note 111.

${ }^{114} \mathrm{Id}$.

${ }^{115} I d$ at $52-53$

${ }^{116} \mathrm{Id}$. 
informally and then formally) long before such financing formally existed particularly for blacks. ${ }^{17}$

Agents and developers who buy on behalf of clients with cash have more leverage - they can buy more confidently and elicit better terms. The efficiency of black West Indians in acquiring property in their islands of origin was undergirded by a set of rules, namely rules which solved collective action problems by allowing land brokers to buy land in trust on behalf of other West Indians, secure in the knowledge that the cash would be found. ${ }^{118}$ Rules also protected future land-owners from unscrupulous trustees. ${ }^{119}$

Similarly brokers in New York had significant opportunities for opportunistic behavior. Yet, they rarely ran off with the money of their fellow West Indians, because such behavior would have entailed communal expulsion. Thus patterns from the West Indies replicate themselves in New York.

\section{Anecdotal evidence to support this theory: What we know from the historical sources}

Modern studies clearly state that West Indians are more likely to occupy higher quality housing either as homeowners or renters than African Americans. ${ }^{120}$ Moreover, they are more likely to live in integrated communities. ${ }^{121}$

The question becomes: How far back does this evidence go? How do we know that West Indians were better placed (in relation to African Americans) with respect to property rental and acquisition? It bears emphasis that there is virtually no empirical work on comparative housing stock between West Indians and African-Americans in the first half of the twentieth century, even as they were both began migrating to New York in significant numbers at about the same time. ${ }^{122}$ However, we can piece together from other historical sources ample evidence that West Indians were more likely to live in majority white communities or mixed black-white communities. ${ }^{123}$ Moreover, these same sources support the view that West Indians have had

${ }^{117} \mathrm{Id}$.

${ }^{118} I d$.

${ }^{119} \mathrm{Id}$.

${ }^{120}$ RoSENBAUM \& FRIEDMAN, supra note 1.

${ }^{121} I d$.

122 I should further note the controversial implication is that West Indians are useful as a comparative "sample" since West Indians were arriving in Northern cities in significant numbers at around the same time that significant numbers of African Americans were migrating from the South.

${ }^{123}$ WATKINS-OWENS, supra note 19; Holder, supra note 110; see also New York Times articles, infra note 170. 
better access to housing, and were also able to occupy higher quality housing in the early $20^{\text {th }}$ century than African-Americans. ${ }^{124}$

Extrapolating from this early evidence to modern demographic studies, one study goes as far as to contend that despite being black West Indian, New Yorkers had a pattern of ascent in the housing market that is most appropriately described as "ethnic." 125 Thus, in the housing market, West Indians are more appropriately analogized perhaps to Italian, Irish or Jewish New Yorkers than to African Americans. ${ }^{126}$

While made specifically in the context of the housing market, this argument seems to channel the sociologists, Moynihan and Glazer's wellknown contention that although they were overwhelmingly black, West Indians' pattern of socioeconomic ascent in New York, was not unlike that of "white ethnics." 127 Yet another historian has argued that that despite being Black, West Indian New Yorkers have historically exercised what he terms an "ethnic option" (typically available to white ethnics), not available to native African Americans of choosing housing accommodations in higherquality neighborhoods. ${ }^{128}$

Despite the absence of empirical work on comparative housing stock between African-Americans and West Indians in the early $20^{\text {th }}$ century, this is a literature to be reckoned with. ${ }^{129}$ Indeed, the sources utilized to justify these contentions are voluminous, not unlike those typically used by historians of black life at the time, including, journalistic accounts (New York had a very vibrant black press from early in the $20^{\text {th }}$ century), and personal diaries. ${ }^{130}$ In the absence of empirical evidence, I must rely instead on a narrative-based methodology (an admitted limitation based on the evidence of the period).

From this literature, we know the following. West Indians dominated the black realtor market starting early in the Twentieth Century. ${ }^{131}$ By way of background, in a segregated housing market, the realtor businesses were similarly segmented. ${ }^{132}$ Thus, there existed a white realtor segment and a black realtor segment. ${ }^{133}$

Black realtors were particularly important players in a period of rapid black migration (of African-Americans from the South and of West Indians

\footnotetext{
${ }^{124}$ WATKINS-OwENS, supra note 19; Holder, supra note 110; see also New York Times articles, infra note 170 .

${ }^{125}$ ROSENBAUM \& FRIEDMAN, supra note 1.

${ }^{126} I d$.

${ }^{127}$ See GlaZer \& Moynihan, supra note 3 at 34-36 (noting that West Indians were generally more successful than the "native" Blacks in America); see also REID, supra note 3, at 119 (providing a broad exploration of the experience of West Indian immigrants to the United States, including their large contributions to the business community).

${ }^{128}$ SCHMIDT, supra note 1 at 111.

${ }^{129}$ Watkins Owens makes wonderful use of these sources and I am partly reliant on her. See WATKINS-OWENS, supra note 19.

${ }^{130}$ See the Introduction to Watkins Owens for a discussion of her methodology. Id. at I.

${ }^{131}$ Id., see also Wilfred Bain, Negro Real Estate Brokers, NEW YORK AGE, Feb. 19, 1921

132 WATKINS-OWENS, supra note 19.

${ }^{133} I d$.
} 
from the islands), which led to a significant demand for housing among blacks. ${ }^{134}$ Given the racial segmentation of the real estate market, high levels of black demand for property put upward pressure on prices in black communities. As the black "middle men," West Indian realtors acted as "gobetweens" between blacks seeking to sell to other blacks, but also as gobetweens between white homeowners and black buyers. ${ }^{135}$

In one sense, the emphasis of West Indian success in the real estate sector in the literature was not atypical; the West Indian dominance of business has long been the subject of significant sociological inquiry. Indeed, the iconic West Indian businessman first came to prominence in the literature a century ago during the Harlem Renaissance ${ }^{136}$ and nowhere was the West Indian influence in business more comprehensive than in real estate. Yet it still bears emphasis that the presence of a core of West Indian real estate agents in the early 1900s was remarkable as this was a profession in which racial minorities and women were notoriously poorly represented until quite recently. ${ }^{137}$ The most successful realtors were those who were able to take advantage of the aforementioned defectors from the norms of racial exclusivity, as was discussed in the previous section. ${ }^{138}$ In the next section, I discuss a case study of one particular West Indian realtor who was able to do this particularly successfully.

\section{E. Tipping}

A series of articles in prominent papers like the New York Times, detail several streets in which whites and blacks were living in close proximity in the first two decades of the Twentieth century, primarily, in the more elite

\footnotetext{
${ }^{134} I d$.

${ }^{135} \mathrm{Id}$.

${ }^{136}$ See Calvin B. Holder, Making Ends Meet, supra note 112 at 52-54 (1998) (noting the relative entrepreneurial success of West Indian Blacks after 1920 as compared to other Blacks in America); George Edmund Haynes, The Negro at Work in New York City: A Study in Economic Progress 101, 108 (Apr. 1, 1912) (unpublished Ph.D. dissertation, Columbia University) (on file with the New York University Law Review) (documenting the disproportionate share of West Indian business proprietors in 1909 in relation to their proportion in the Black population); It was clearly documented in the 1930s that West Indians were disproportionately represented among Black professionals in New York City. See Holder, Making Ends Meet, supra note 112 at 53-54 (1998) ("By the 1930s, ... West Indians were clearly the majority of black businesspersons in New York and were, for all intents and purposes, the only blacks with businesses connected to the skilled trades.”); John C. Walter, The Caribbean Immigrant Impulse in American Life: 1900-1930, 11 REVISTA INTERAMERICANA 522, 529-30 (1981). James offers a comprehensive critique of the notion that West Indians are "exceptional." See James, Explaining Afro-Caribbean Social Mobility, supra note 3 at 241 (claiming that selective migration and previously acquired skills influenced the advancement of West Indians in the United States, and using data to "remove the aura of magic and mystery from their trajectory in the United States").

${ }^{137}$ There is not much academic work in this area, but it is telling that for example, the New Haven Real Estate Board had virtually no female and black members in the 1950s. See Stuart H. Palmer, The Role of the Real Estate Agent in the Structuring of Residential Areas A Study in Social Control 49 (1955) (unpublished Ph.D. dissertation, Yale University) (on file with the Yale University Library).

${ }^{138} I d$.
} 
sections of Harlem like Sugar Hill. ${ }^{139}$ Notably, many of the blacks discussed in these articles were owners rather than renters. These blacks were overwhelmingly West Indians who had come from the islands with cash reserves, few native African Americans were in a position to rent (much less own) homes in these areas at this time. ${ }^{140}$

While these communities co-existed with a few blacks, white flight quickly ensued once blacks began to move in significant numbers into the larger Harlem community (as opposed to its most elite sections). ${ }^{141}$ Heeding the call of the African American "father of Harlem", the realtor Phillip Payton, that it was possible to "make money from racism," 142 the wellknown Barbadian millionaire speculator, Solomon Riley began a pattern of behavior that bears a resemblance to what later became known as "blockbusting." 143

Riley's narrative is of particular interest. Long a millionaire, he resided on a very tiny Harlem street alongside whites. ${ }^{144}$ At first his tenure was peacable, but when other blacks began to express an interest in the area, his neighbors expressed increasing displeasure at his presence in the neighborhood. ${ }^{145}$ Previously, he believed that he had been protected by the widespread disbelief among whites that there were other blacks rich enough to move into the more affluent sections of Harlem. ${ }^{146}$ To add insult to injury, his wife was white at a time when inter-racial marriage still met with widespread societal disapproval. ${ }^{147}$

Riley later told his tale to a New-Deal era Works Progress administration researcher, who was conducting federally funded research on the history of Harlem. ${ }^{148}$ Given increasing expressions of hostility from his neighbors, he moved. ${ }^{149}$ In an effort to extract revenge on his bigoted neighbors, he then deliberately sought a black family to whom he could lease the property. ${ }^{150}$ Having sought to eject one black family, he wanted to make the point that they would simply find themselves with another. ${ }^{151}$

Athough Riley argues that he was simply motivated by revenge, it is worth mentioning that his actions might have been motivated by economic self-interest. By way of background, as more blacks moved to New York, and white communities reacted with hostility by "penning" blacks into

139 OSOFSKY, supra note 43.

${ }^{140}$ WATKINS-OWENS, supra note 19 at 41-48; Theodore Poston, Negro Millionaire Solomon Riley (WPA biography).

${ }^{141}$ Poston, supra note 140; WATKINS-OWENS, supra note 19.

142 WATKINS-OWENS, supra note 19 at 41-48.

${ }^{143}$ Poston, supra note 140.

${ }^{144} \mathrm{Id}$.

${ }^{145} \mathrm{Id}$.

${ }^{146} I d$.

${ }^{147} \mathrm{Id}$.

${ }^{148} I d$.

${ }^{149} I d$.

${ }^{150} I d$.

${ }^{151} I d$. 
particular areas, housing became difficult to secure for blacks generally. ${ }^{152}$ Notably, this was increasingly true even for affluent blacks. ${ }^{153}$ Thus, Riley could surely have extracted a premium from a black tenant (that he would not necessarily have been able to extract from a white tenant). Given the black housing shortage in a racially segregated market, the opportunities for arbitrage were significant. ${ }^{154}$

Riley's narrative continues: his white neighbor, panicking at the evidence of yet another black family with the resources needed to move into the neighbood, decided that he would no longer stay and moved at short notice. ${ }^{155}$ Riley, by his account, did nothing to disabuse his former neighbor of the notion of a pending black onslaught (one cannot help wondering whether he helped feed the panic). ${ }^{156}$

Sensing an opportunity, he bought his neighbors home at a discount. In an effort to increase the likelihood that his former neighbors would sell, his wife conducted transactions on his behalf and he often bought properties in her name. ${ }^{157} \mathrm{He}$ then moved yet another black family into his former neighbor's home as tenants. ${ }^{158}$ And then another neighbour moved. ${ }^{159}$ And so he found himself building quite an asset base by acquiring tiny townhouses at significant discounts as panicked whites moved in a hurry. ${ }^{160}$ Notably, since there remained so few places for blacks generally to rent (and particularly so few elite places), he remained able to charge premium rents for his newly aquired townhouses. ${ }^{161}$

Features of this story stand out. First, Riley was in the neighborhood in the first place because he had the cash. If his account is credible, his early acceptance by his neighbors seemed based on their perceptions that few blacks would be in a position to buy the property.

Moreover typically in a racially segregated housing and realtor market, tipping would require the cooperation of both black and white agents - white agents to service the families moving out and black agents to provide service to the families moving in. ${ }^{162}$

Yet as Riley tells the story, he was not acting in concert with white agents to "tip" the neighborhood. ${ }^{163}$ On the contrary, he was a homeowner. ${ }^{164}$ Neighbors created a hostile environment which led his family to exit the neighborhood, and his neighbors got their "just deserts"

${ }^{152}$ OSOFSKY, supra note 43.

${ }^{153} \mathrm{Id}$.

${ }^{154}$ Melhorn makes this point, albeit in a later time period. See MELHORN, supra note 67.

${ }^{155}$ Poston, supra note 140.

${ }^{156} I d$.

${ }^{157} I d$.

${ }^{158} I d$.

${ }^{159} I d$.

${ }^{160} \mathrm{Id}$.

${ }^{161} I d$.

${ }^{162}$ Melhorn makes this point. See MELHORN, supra note 67.

${ }^{163}$ Poston, supra note 140.

${ }^{164} I d$. 
when black tenants moved in. ${ }^{165}$ Indeed, he could quite reasonably have argued that they should have reasonably forseeen that the future tenants would be black. ${ }^{166}$ That is, given the racial temper of the period, one could not reasonably have expected whites to rent from a black man. ${ }^{167}$

Although the fact that his wife often conducted transactions on his behalf probably helped, this could hardly have remained a secret for long. ${ }^{168}$ While hiding behind his wife could be construed as "passing," (or if not, "covering") the success of "passing" as a strategy is inextricably intertwined with ignorance of the black identity of the ultimate buyer. It is unclear that "passing" would have worked in the long term given the notoreity that ultimately accompanied Riley's acquitions.

But it bears emphasis that Riley could quite reasonably have provided a self-interested account. Riley might well have been involved in deliberately eliciting racial tipping. Given the opportunities for arbitrage, it is perhaps inevitable that agents would begin to act as Riley did. Moreover, as a simple matter of business efficiency, it is eminently understandable that Riley could justify his behavior as simply satisfying the preferences of his black clients who preferred to live with blacks. ${ }^{169}$

For example, one account of the period from the New York Times suggests that white and black players were acting in concert to "tip" neighborhoods. ${ }^{170}$ One owner of several buildings in Harlem, Mr. Meyer

\footnotetext{
${ }^{165} I d$.

${ }^{166} I d$.

${ }^{167}$ Indeed, decades later, a study by the author Rose Helper makes this point. It was widely believed that white could not be expected to rent from blacks, even if the larger neighborhood was white. Rose HELPER, RACIAL POLICIES AND PRACTICES OF REAL ESTATE BROKERS 143-54 (1969).

${ }^{168} I d$.

${ }^{169}$ See Palmer, supra note 137. ("[R]acial steering is attractive to brokers on grounds of simple business efficiency. The quickest and surest sales can be mad by satisfying buyer preferences, which brokers assume to be for neighborhoods inhabited by members of the buyer's own race." (citing Musa Bish et AL., Racial SteERING.The Dual Housing Market and Multiracial NEIGHBORHOODS 12 (National Neighbors 1973))). Notably, a team lead by the economist Rawle Farley found that blacks consistently expressed preferences for living among other blacks (this research was conducted decades after Riley's foray into real estate investing in Harlem). See Reynolds Farley et al., Barriers to the Racial Integration of Neighborhoods: The Detroit Case, 441 ANNALS AM. ACAD. POL. \& SOC. SCI. 97 (1979).

${ }^{170}$ See relevant articles from the New York Times:

1. A Race Prejudice Mint for Profits in Realty, N.Y. TimES, Oct. 27, 1906, available at http://query.nytimes.com/mem/archivefree/pdf?res=9E05E3D9173EE733A25754C2A9669D946797D6CF.

2. Real Estate Race War is Started in Harlem, N.Y. TIMES, Dec. 17, 1905, available at http://query.nytimes.com/mem/archivefree/pdf?_r=1\&res=9B00E4DB153AE733A25754C1A9649D946497D6CF

3. Negroes Move into Harlem, NEw York HERALD, Dec. 24, 1905. Quoted in Sharifa Rhodes-Pitts, Harlem Is Nowhere, Excerpt, N.Y. TIMES, Jan. 25, 2011.

4. Negro Invasion Threat Angers Flat Dwellers, N.Y. TIMES, July 21, 1906, available at http://query.nytimes.com/mem/archivefree/pdf?res=9502E0DC173EE733A25752C2A9619C946797D6CF.
} 
was cited as an owner who appeared to be acting in concert with black realtors. (Given the racial temper of the time period, one cannot help wondering whether anti-Semitism underlies the New York Times focus on Mr. Meyer). ${ }^{171} \mathrm{Mr}$. Meyer was accused of notifying white tenants that they would have to vacate, shortly before selling to cash-rich blacks (represented by black realtors). These black buyers would then quickly fill the building with black tenants. ${ }^{172}$

Moreover, Mr. Meyer was accused of heaping further indignities on his former white tenants, some of whom were unable to secure replacement housing given the short notice. ${ }^{173}$ These whites found themselves having to negotiate for lease extensions with the new black owners through their black agents who were largely West Indians. ${ }^{174}$ The New York Times notes that the indignity was even further compounded by the fact that blacks began to move into their buildings very shortly after the buildings were transferred to black owners -- thus white (former) tenants found themselves living temporarily beside black (new) tenants.

While other West Indians in the property business did not provide such rich historical accounts as Riley, the historian, Watkins-Owens notes that it is likely similar strategies were utilized by Adolph Howell, a West Indian principal in the Sphinx Realty Company, and William Roach, a phenomenally successful Montesseratan who was principal in the Sarco Realty Company. ${ }^{175}$ That is, having bought low from fleeing whites, they sold or leased high to blacks who were desperaate for decent real estate. Notably, Sarco was dominant not only in residential housing in Harlem but also owned several presitgious commercial addresses in Harlem.

It is not that these "tipping" patterns were exclusive to West Indians. Indeed, African Americans realtors undoubtedly replicated similar patterns, and in fact preceded their West Indian peers. Yet while African American realtors, such as Phillip Payton and John Nail, first opened Harlem in the first

5. “23” The Mystic Sign on Negro Flathouse, N.Y. TimES, July 22, 1906, available at http://query.nytimes.com/mem/archivefree/pdf?res=F50F13FA395512738DDDAB0A94DF405B868CF1D3

6. Negroes Charge Payton With Realty Fraud, N.Y. TIMES, Jan.30, 1907, available at http://query.nytimes.com/mem/archivefree/pdf?res=9F0DE0D8153EE033A25753C3A9679C946697D6CF.

7. Negro After Fine Estate, N.Y. Times, Jan. 23, 1912, available at http://query.nytimes.com/mem/archivefree/pdf?res=9504E0DE173CE633A25750C2A9679C946396D6CF.

8. Apartment Homes for Negro Tenants, N.Y. Times, July 11, 1917, available at http://query.nytimes.com/mem/archivefree/pdf? res $=9404 E 0 D B 133 B E 03 A B C 4952 D F B 166838 C 609 E D E$.

${ }^{171}$ Negro Invasion Threat Angers Flat Dwellers, supra note 170.

${ }^{172} \mathrm{Id}$.

${ }^{173} I d$.

${ }^{174}$ Real Estate Race War is Started in Harlem, supra note 170.

175 WATKINS-OWENS, supra note 19. 
decade of the Twentieth Century, few of their companies lasted. ${ }^{176}$ This is unsurprising - indeed, many white realty companies were unable able to survive the extended downturn of the Great Depression. West Indian realtors were often not only brokers, but also real estate developers. Given the poor availabilty of credit generally at the time (and particularly for black businessmen), many of the West Indian purchases were cash purchases. All this is to say that although some of the West Indian broker/developers failed during the Great Depression, they appear to have had deeper reserves, and longer staying power thant their African American peers in this difficult period.

A pattern of West Indian dominance of Black access to segregated housing markets through their control of the realty business appears to have been present throughout New York. Their influence extended outside of Harlem. In Brooklyn, for example the Carringtons were prominent Black players in residential real estate. ${ }^{177}$ Fellow West Indians were believed to have privileged access to homes that the Carringtons controlled.

\section{F. Related factors that allowed West Indians to quickly consolidate their gains}

There were related factors that allowed West Indians to quickly consolidate their gains in these neighborhoods. For example, there appear to have been integration across housing-related businesses, so that West Indian advantages in one line of business carried over to another. For instance, the Paragon Credit Union, which provided mortgage support to Brooklyn-based West Indians (especially Barbadians), received referrals primarily from the Carrington brothers. ${ }^{178}$ The same referral process appears to have been important to the West Indian-founded Victory Insurance Company, which provided insurance for West Indian-owned homes and businesses. ${ }^{179}$ In addition, Watkins-Owens documents a plethora of far smaller but highly

\footnotetext{
${ }^{176} \mathrm{Id}$.

${ }^{177}$ Id. at 55 .

${ }^{178}$ See id. at 58 (describing how the availability of legitimate capital allowed West Indian immigrants to purchase homes). See also, Crowder, supra note 1, at 106-07 (discussing West Indian systems of credit as one of many reasons why West Indians may have ended up in neighborhoods thought to be of a higher quality). Similarly, sociologist Roger Waldinger argues that early "Caribbean immigrants engaged in considerable property speculation, with the result that real estate had emerged as a small, but still significant, Caribbean niche by the eve of World War II." Roger WAldinger, Still the PROMised City? AFricAN-AMERICANS AND NeW IMMIGRANTS IN POSTINDUSTRIAL NEW YORK 119 (1996).

${ }^{179}$ There were several other successful West Indians who through their realty businesses exercised substantial influence over Black access to real estate and affiliated businesses in New York. An early successful Black-owned department store in Harlem, Hart and Company, was launched by Arthur Hart, a Jamaican, and was managed and staffed by Caribbean Blacks. See WATKINSOWENS, supra note 19, at 43, 132.
} 
influential West Indian real estate market participants. ${ }^{180}$ For example, there were hundreds of operators of boarding houses who provided West Indian renters with an early foothold in neighborhoods where they would later

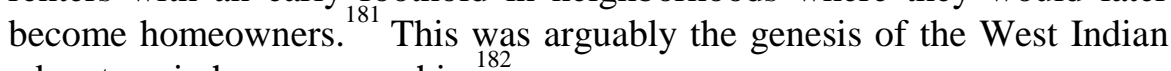
advantage in home ownership.

\section{ANALOGIES TO WEST INDIAN HISTORY}

\section{A. Map of this section}

By way of background, in the early decades of the $20^{\text {th }}$ Century when West Indians started arriving in New York, homeownership in the US was largely limited to whites with resources. ${ }^{183}$ Blacks (although their numbers were miniscule) and poorer whites were essentially excluded from homeownership. ${ }^{184}$ Homeownership did not become more broadly based until federal government intervention in the home mortgage market decades later. ${ }^{185}$ Even later, when poorer whites gained access to federal financing for home mortgages, blacks were typically excluded from such programs. ${ }^{186}$ This section summarizes how they were able to sidestep such exclusions their initial success in busting such cartels was critical.

In this section, I also provide further evidence for the argument that with respect to residential segregation in the early decades of the Twentieth Century, West Indians are not necessarily an appropriate comparative group to African Americans. Notably, West Indians had multiple tools at their disposal (borne of their experience and capital gained in the West Indies) in "busting" racial cartels in real property. ${ }^{187}$ That is, tools that worked well in the West Indies translated well to New York.

\footnotetext{
180 See id. at 42-43 (including "Millionaire Solomon Riley" in land speculation, John E. Nail and Henry C. Parker in the real estate firm of Nail and Parker, and A.A. Austin in the Antillean Holding Company, among others).

${ }_{181}$ See id. at 43 (noting that many Caribbean families would become landlords and rent rooms to the expanding Black population after purchasing their property).

182 Cf. Crowder, supra note 1, at 106-07 (discussing West Indian systems of credit); Waldinger, supra note 178.

183 See William J. Collins \& Robert A. Margo, Race and Home Ownership from the End of the Civil War to the Present, 101(3) Am. Econ. Rev. 355-359 (2011); see also Trevor M. Kollmann \& Price V. Fishback, The New Deal, Race, and Home Ownership in the 1920s and 1930s, 101(3) Am. Econ. Rev. 366-70 (2011); William J. Collins \& Robert A. Margo, Race and Home Ownership: A Century- Long View, 38 EXPLORATIONS IN ECON. HIST. 68- 92 (2001).

${ }^{184}$ See Collins \& Margo, Race and Home Ownership from the End of the Civil War, supra note 183.

${ }^{185}$ Id.

186 Adam Gordon, The Creation of Homeownership: How New Deal Changes in Banking Regulation Simultaneously Made Homeownership Accessible to Whites and Out of Reach for Blacks, 115 YALE L.J. 186 (2005).

${ }^{187}$ See infra, Part III.
} 
Indeed, there are repeated instances of West Indians "busting" white (British) monopolies in land-ownership, throughout the British West Indian colonies in contravention of racial norms of who was allowed to own land where. ${ }^{188}$ Applying Hirschman's classic framework of "voice," "exit," and "loyalty," 189 I note that in the aftermath of the abolition of slavery, former West Indian slaves were given a "choice" of remaining on sugar plantations in relationships that approximated sharecropping ("loyalty") as opposed to leaving the plantations ("exit"). ${ }^{190}$

Of course, this was never really meant by the plantocracy to be a "choice" for newly freed blacks. ${ }^{191}$ Rather, the plantocracy was seeking to institute a system of tenancy rent (that is, sharecropping) as a mechanism of reducing cash outflows from their sugar plantations. Under this system, planter would "lease" the land to the newly freed slave in return for a share of the crops on the land (or some other in-kind rental payment). ${ }^{192}$ Emancipation greatly increased the "cash crunch" faced by planters. Indeed, cash outflows from plantations would necessarily have increased given the now-free labor (previously unfree slave labor) who needed to be paid. ${ }^{193}$ Tenancy rent provided a mechanism of reducing cash outflows for creditconstrained farmers. ${ }^{194}$

To this end, the plantocracy, utilized every mechanism at their disposal to prevent newly freed West Indians from buying land. ${ }^{195}$ After all, freedmen

\footnotetext{
${ }^{188}$ See infra Part III.

${ }^{189}$ See AlBERT HiRSCHMAn, EXIT, VOICE AND LOYALTY (1970).

${ }^{190}$ See infra Part III.

${ }^{191} I d$.

192 The economist Harris summarizes the economics literature on tenancy rent; he notes a system of tenancy rent is particularly attractive for credit-constrained planters:

"One obvious advantage of this strategy of combining rents and wages ... is that it allows the planter to cover some or all of the working capital advanced as wages from the current flow of rents paid by the tenants. In effect, what the planter pays out in one hand as wages to the workers is what he gets as rents in the other hand from the tenants. Thereby is resolved, at least partially, the cash flow problem of the planter. Or, more generally, the existence of tenancy rent reduces the net cash requirements that the planter must meet and, hence, the credit obligations that he must incur. The second advantage of this strategy of combining land tenancy and wage-labour is that it allows the workers (and/or their families) to grow their own food (directly or through exchange of products) on the plots of tenanted land and there by reduces the amount of cash the planter must advance as money wages to the workers. For this purpose, a system of sharecropping or of sharing labour service would do as well as a system of payment of rent (in cash or in kind). The third advantage of this arrangement, from the stand point of the individual planter, is that the planter is able to obtain an almost guaranteed access to a regular supply of labour through effectively tying the labour to his land through the granting of concessions and rights to the use of land by the family of the worker." Donald J. Harris, The Circuit of Capital and the 'Labour Problem' in Capitalist Development, 37 (1 \& 2) SOC. \& ECON. STUD. 15, 26 (1988). Some classic contributions in this share tenancy literature are ALFRED MARSHALL, PRINCIPLES OF ECONOMICS (London: Macmillan and Co., $8^{\text {th }}$ ed. 1920); Steven N. S. Cheung, Transaction Costs, Risk Aversion, and the Choice of Contractual Arrangements, 12(1) J. L. \& ECON. 23-42; Joseph E. Stiglitz, Incentives and Risk Sharing in Share Cropping, 41 REV. ECON. STUD. 219-255(1974).

${ }^{193}$ See infra Part III.

${ }^{194} \mathrm{Id}$.

${ }^{195} I d$.
} 
who were already land-owners were unlikely to sign up for sharecropping. 196 That is, the plantocracy sought to maintain a racial cartel in landownership.

Yet, West Indians overwhelmingly chose "exit." 197 They were facilitated in large part by self-interested white defectors, who were seeking to "cash" out their plantations and were willing to transgress norms of racial exclusivity to achieve these ends. ${ }^{198}$ They were also facilitated by the development of a black land-brokering class, who acted as trustees for black buyers, pooled cash, identified white defectors and acted as go-betweens for planters willing to sell and freedmen with cash. ${ }^{199}$

\section{B. The Prelude: Property during Slavery}

Prior to the American Revolution, the American colonies and the West Indies (as British colonies) had similar historical trajectories. ${ }^{200}$ There is good reason for the focus of historians on the West Indies, despite its small size - it was in the West Indies that plantation slavery was "perfected" (to use the words of Ulrich Phillips, the early historian of the U.S. South) before it was "exported" to other colonies (such as the then British-colonized Carolinas). ${ }^{201}$ It was precisely this point that Ulrich Phillips, the early American historian of the U.S. South, emphasized:

As regards negro slavery the history of the West Indies is inseparable from that of North America. In them the plantation system originated and reached its greatest scale, and from them the institution of slavery was extended to the continent. The industrial system on the islands, and particularly on those occupied by the British, is accordingly instructive as an introduction and a parallel to the continental regime. ${ }^{202}$

\footnotetext{
${ }^{196} I d$.

${ }^{197} I d$.

${ }^{198} I d$.

${ }^{199} \mathrm{Id}$.

${ }^{200}$ See Roderick A. McDonald, The ECONOMy AND Material Culture of Slaves: Goods AND CHATTELS ON THE SUGAR PlANTATIONS OF JAMAICA AND LOUISIANA (1993) (conducting a comparative study of slavery in the West Indies and in parts of the American South).

${ }^{201}$ The classics in this area are too numerous to mention in a brief footnote. For a good introduction to the literature in the area, you can hardly do better than THE SLAVERY READER (Gad Heuman \& , James Walvin eds., Routledge 2003), which has an extensive introduction to plantation slavery as an institution, particularly in the West Indies.

${ }^{202}$ UlRICH B. PHILLIPS, AMERICAN NEGRO SLAVERY: A SURVEY OF THE SUPPLY, EMPLOYMENT AND CONTROL OF NEGRo LABOR AS DETERMinED bY THE Plantation RÉGIME 46 (1918). As the historian Betty Wood establishes, most early African slaves who were imported into the English colonies (that later became the United States) came from the West Indies. Prior to the early 1700s, it was difficult to acquire slaves from Africa in the colonies that became the United States; most Africans were sold in the West Indies. One of the early large-scale importations of African slaves in the American colonies occurred when Barbadian planters-who played a significant role in the
} 
Whatever early institutional similarities there may have been between the plantation systems in the West Indies and the U.S. South, the institutional differences between the West Indies and the U.S. South will be clear to many readers, even as I do not typically make overt comparisons to plantation slavery in the U.S. The two critical features of the West Indies were first, its relative isolation and second, the precarious nature of shipping routes (on which planters were initially dependent to import food to feed slaves). ${ }^{203}$

These features of the West Indies ultimately became critical to the evolution of property arrangements among the slave ancestors of West Indian property owners who later migrated to the United States. Another relevant feature of the West Indies was its economic importance to the Exchequer (British Treasury). Indeed, Jamaica at the peak of its productivity in the eighteenth century was among the most valuable colonies, worth significantly more than all of the New England colonies combined. ${ }^{204}$

In my view, these features of the political economy of the West Indies provided incentives for the plantocracy to innovate in property and contracting arrangements with respect to the slave population. ${ }^{205}$ Their important task was to get the slaves to feed themselves. To achieve this goal, importantly they had the support of the British Parliament. Thus, critical interests were aligned in achieving this goal: Parliament, the plantocracy, plantation financiers and the slave population (which far outnumbered the British population).

If the slaves could feed themselves, there would be less of a stress on precious plantation working capital (no cash outlays needed to import expensive food from London utilizing precarious shipping routes), Parliament would not need to entertain pained reports from the colonies about how slave malnutrition was compromising plantation productivity, and

founding of South Carolina in 1670-imported slaves from Barbados. See BETTY WoOD, THE ORIGINS OF AMERICAN SLAVERY 64-65 (1997) (discussing the connection between the Lowcountry, as the English called present-day South Carolina, and settlers from Barbados).

${ }^{203}$ The historian Selwyn Carrington is a particularly strong proponent of the influence of war, which has been disputed by other historians and summarized neatly in Veront Satchell, Sugar Slavery and Technological Change: Jamaica 1760-1830 (2010) (noting Carrington's argument that the American Revolutionary War prompted the decline of the British West Indies as "Caribbean sugar producers were extremely dependent on British North America for all commodities necessary for them to produce sugar").

204 The islands, and particularly Jamaica, had become important to the economic wellbeing of the British Empire as a major source of revenue for the British Treasury, which levied ample taxes on the planters' profits. See PHILIP SHERLOCK \& HAZEL BENNETT, THE STORY OF THE JAMAICAN PEOPLE at 281-82 (S1998) (discussing the high customs duties on consumer goods). As an epicenter of sugar exportation and slave importation in the British empire, Jamaica had long been a regional shipping center. See SELWYN H.H. CARRINGTON, THE BRITISH WEST INDIES DURING THE AMERICAN REVOLUTION 32-33 (Brill 1998) (noting that as early as the American Revolution, Jamaica's exports to Britain exceeded those of the far larger American colonies that would become the United States); Sidney W. MintZ, Caribbean Transformations 60 (2d ed. 1989) (summarizing Phillip Curtin's finding that only Saint Domingue (later Haiti) and Brazil, far larger countries, imported larger number of slaves than Jamaica in the region).

${ }^{205}$ See infra Part III. 
the Treasury's coffers could continue to rely on plantation taxes. ${ }^{206}$ Financiers could rest easier knowing that it was more likely that planters would pay their debts. Moreover, the slaves were eager for a system that would keep them better fed. ${ }^{207}$

As economists have long told us, secure entitlements incentivize effort; commerce increases the payoff from effort even more. ${ }^{208}$ The plantocracy implicitly understood this with respect to local food production; they supported informal slave entitlements in plots to grow food and the produce that came from these plots. ${ }^{209}$ These plots came to be known as "provision grounds", and the rights that surrounded them looked very much like formal property rights, although the regime was essentially informal. ${ }^{210}$

The result was the evolution of a slave culture involving increasingly complex forms of property arrangements - which I have termed in a separate paper "de facto property rights", including inheritance-like devices. ${ }^{211}$ These slaves became what I term "property holders" in waiting. ${ }^{212}$

Demsetz's classic paper on property rights argued that "the emergence of new property rights takes place in response to the desires of the interacting persons for adjustment to new benefit-cost possibilities." 213 The thesis is very Demsetzian - property rights emerged for slaves (who were themselves property) in response to the demand for them at multiple levels of plantation society. ${ }^{214}$ Moreover, not only were slaves property holders; slaves also were contractors, increasingly engaging in commerce; they became the dominant players in the food economy. ${ }^{215}$

\section{Emancipation}

The system of allocating provision lands (property-lite) to the slaves was widely supported at multiple levels of plantation society during

\footnotetext{
${ }^{206}$ See Brown, supra note 111.

${ }^{207} \mathrm{Id}$.

${ }^{208}$ The classic in this regard is Harold Demsetz, Toward a Theory of Property Rights, 57 AM. ECON. REV. 347 (1967) (discussing "guidance for investigating the emergence of property rights"). For a discussion of the importance of this article, see Thomas W. Merrill, Introduction: The Demsetz Thesis and the Evolution of Property Rights, 31 J. LEGAL STUD. S331, S331 (2002) ("The point of departure for virtually all efforts to explain changes in property rights is Harold Demsetz's pathbreaking article, 'Toward a Theory of Property Rights.' The article is still widely cited and reproduced . . . "); ItAi SENED, The Political Institution OF PRIVATE PROPERTY 34 (1997) ("One of the most influential neoclassical theor[ies] of . . . property rights is due to Harold Demsetz.")

${ }^{209}$ Brown, supra note 111.

${ }^{210} I d$.

${ }^{211} I d$.

${ }^{212} I d$.

${ }^{213}$ Demsetz, supra note 208, at 350.

${ }^{214}$ Brown, supra note 111.

${ }^{215} I d$.
} 
slavery. ${ }^{216}$ Emancipation threatened to turn everything upside down. ${ }^{217}$ Once labor becomes free, this relationship of reciprocal obligation (which is fundamentally a status relationship) is completely severed. ${ }^{218}$ Any contractual relationship (be it one grounded in tenancy or employment) is fundamentally far more tenuous for the planter than a relationship grounded in status. ${ }^{219}$

And what to do with the property which the slave occupies but the planter has legal title to, i.e. former provision grounds at the edge of the plantation? ${ }^{220}$ If the freedman continues to work for the planter, perhaps there is an ongoing basis for his continuing occupancy of provision grounds at the edge of the plantation on which he can grow food (as he had done during slavery under the previously described informal and innovative arrangements). ${ }^{221}$ In such a case, the planter has a clear justification for the continuing occupation of the land by the former slave -- the slave's ongoing low-cost labor on the plantation can be understood as an in-kind rental payment. ${ }^{222}$ Indeed, such an arrangement may even be beneficial to the planter's cash-flow. ${ }^{223}$ Theoretically, just as the freedman "pays" him for the land through low-cost labor or a share of crops, he "pays" the freedman (in kind), with less of a need for a cash-outlay. ${ }^{224}$

Suppose the freedman declines employment on the plantation? One can expect the planter to ask himself the following: Why is a (former) slave, now freedman, remaining on land that is formally mine if I am no longer obligated to provide for him? What am I getting out of it? Predictably, there was a faceoff between the planters and the newly freedmen.

\section{Exit, Voice, Loyalty}

Prior to full Emancipation, there was a period in which newly freed men served as "apprentices" on plantations. ${ }^{225}$ Apprenticeship was conceived as a mixed slave labor/free labor period to prepare for full Emancipation.

\footnotetext{
${ }^{216} I d$.

${ }^{217}$ The economist, Harris makes this point very well. See Harris, supra note 192.

${ }^{218} I d$.

${ }^{219} I d$.

${ }^{220} I d$.

${ }^{221} I d$.

${ }^{222} I d$.

${ }^{223} \mathrm{Id}$.

${ }^{224} \mathrm{Id}$

225 See SHERLOCK \& BENNETT, supra note 204 at 230 (discussing the apprenticeship system that was enacted throughout the British West Indies and served as a predecessor to full freedom); see also F.A. HOYOS, BARBADOS: A HISTORY FROM THE AMERINDIANS TO INDEPENDENCE 127-30 (1978) (discussing the extensive use of the apprenticeship system and noting that only the colony of Antigua rejected it). In examining Antigua, the lone holdout to the apprenticeship system, Hoyos explains that Antiguan planters argued that apprenticeship was unnecessary, would be expensive, might negatively affect labor relations, and had the potential to incite unrest and revolt. Id. at $127-$ 28.
} 
Although in practice many slaves continued to be treated as they had been in slavery, during an apprenticeship, the slave was technically to be compensated for work beyond the time allocated for compulsory labor. ${ }^{226}$

Upon full Emancipation, the newly fully freedmen were no longer obligated to remain with the plantation. Thus, the options that confronted West Indian freedmen when they sought to exercise their newfound freedom are reminiscent of Albert Hirschman's famous conceptual ultimatum ("voice/exit/loyalty"). ${ }^{227}$ Albert Hirschman famously argued that members of any human grouping (be it a nation, a business, a religious group or a family) have three main options when they perceive that the grouping is no longer beneficial to them. Similarly, the freed slaves had three options.

First, they could remain on the plantation in an employment relationship largely on the planter's terms ("loyalty"). For example, they could continue to accept wages that were as a practical matter planterdetermined. Second, they could remain on the plantation but with a more robust set of protections. These protections would include guaranteed leave (particularly for the women who wanted guaranteed days off to prepare for weekend markets where slave-grown food was sold), assurances that they could reap crops planted even in the event of a later severing of the employment relationship and eviction, and market determined wages (which would theoretically be subject to some bargaining on the part of freedmen, particularly in those islands where labor was inclined to be short). This would approximate "voice." Those exercising "voice" could extract concessions for their ongoing loyalty.

Notably, although the concessions associated with "voice" should theoretically have allowed them to build assets, for many slaves this was not enough. For these slaves, the better option was "exit." Those who already had assets (particularly land) could actually credibly threaten to exit undesirable plantation relationships, and proceed to do so. My argument is that across the region, exit predominated.

\section{E. Who could exit?}

The likelihood that slaves would exit depended largely on two factors - the availability of cash and the availability of land. Certainly in the earliest days of Emancipation, any cash that the slaves had would have most

\footnotetext{
226 As described in detail:

Apprenticeship was a half-way covenant in which the relationship between the planter and the worker was much the same as that between master and slave for forty and onehalf hours of the work week, but during the balance of the week they were to assume the respective statuses of employer and employee freely negotiating conditions of work and wages.

See Thomas C. Holt, The Problem of Freedom: Race, LABor, ANd Politics in JAMAicA AND BRITAIN, 1832-1938 at 56-57 (1992)..

${ }^{227}$ See HIRSCHMAN, supra note 189.
} 
likely been accumulated during slavery. ${ }^{228}$ The availability of cash with which they could buy land was in turn tied to the extensiveness of the provisioning system (during slavery), that allowed them to grow crops which they could then market, in a particular island. ${ }^{229}$

A primary reason that the West Indies is such a wonderful place for a comparative study of the evolution of property regimes (in practice as opposed to just in law) is that there were distinct topological and size differences between the islands that had significant implications for land allocation, both during and after slavery. It provides a wonderful (and admittedly informal) "natural experiment" through which to view the thesis offered here: that is where freedmen had options, exit predominated, with a corresponding "busting" of racial cartels in land-ownership.

For example, some colonies (Guyana, Jamaica, Trinidad and Tobago) were larger with more plentiful arable land. ${ }^{230}$ And even when planters were unwilling to give arable land to slaves, there remained more marginal land in close proximity to the plantations on which the slaves could plant. ${ }^{231}$ Other islands (Barbados, St. Vincent, St. Kitts) were much smaller. Planters were less inclined to be generous because every acre given to slave was an acre not available for sugar plantation. ${ }^{232}$ So in these islands, although provisioning did occur, it was more marginal, with garden "plots" as opposed to more fulsome lands. ${ }^{233}$ In Barbados, in particular, which is compromised

\footnotetext{
${ }^{228}$ See SHERLOCK \& BENNETT, supra note 204.

${ }^{229}$ See Harris, supra note 192.

${ }^{230}$ Sidney W. Mintz, The Question of Caribbean Peasantries: A Comment, 1(3) CARIBBEAN STUD. 31-34 (1961); Sidney W. Mintz \& Douglas G. Hall, The Origins of the Jamaican Internal Marketing System, in PAPERS IN CARIBbEAN ANTHROPOlOGY (New Haven 1960); Sidney W. Mintz, Foreword to RAMIRo GUERRA Y SANCHEZ, SUGAR AND SOCIETY IN THE CARIBBEAN (New Haven 1964); Sidney W. Mintz, Labor and Sugar in Puerto Rico and Jamaica, 1800-1850, 1(3) COMP. StUD. IN SoC’Y \& HIST. 273-283 (1959); Sidney W. Mintz, Was the Plantation Slave a Proletarian?, 1 Review II 81-98 (1978) ; Sidney W. Mintz, Historical Sociology of the Jamaican Church-Founded Free Village System, 38 DE WEST INDISCHE GIDS 46-70 (1958); ELSA V. GOVEIA, A STUDY OF THE HISTORIOGRAPHY OF THE BRITISH WEST INDIES TO THE END OF THE NineteEnth Century (Mexico City: Instituto Panamericano de Geografia e Historia 1956); Elsa V. Goveia, Comment on Sidney W. Mintz, Labor and Sugar in Puerto Rico and Jamaica, 18001850 , 1(3) Comp. Studies in Society and History 281-83 (1959); Emanuel W. Riviere, Labour Shortage in British West Indies after Emancipation, 4 J. CARIBBEAN HIST. 1-30 . (1972); Woodville Marshall, Aspects of the Development of the Peasantry, in PEASANT MOVEMENTS AND Agrarian PROBlems IN THE WeSt InDIES, PART L 1-22 (Department of History, U.W.I., Barbados 1969) (mimeographed); Woodville Marshall, THE PEASANTRY AND THE SUGAR INDUSTRY, (Department of History, U.W.I., Barbados 1970) (mimeographed); Woodville Marshall, The Ex-slaves as Wage Labourers on the Sugar Estates in the British Windward Islands 1838-1846 (XI Conference of Caribbean Historians, Curacao, April 1979) [hereinafter Marshall, Ex-slaves]; Woodville Marshall, The Establishment of a Peasantry in Barbados, 1840-1920, in SOCIAL GROUPS AND INSTITUTIONS IN THE HISTORY OF THE CARIBBEAN 84-104 (T. Matthews ed., 1975); Woodville Marshall, Rock Hall: the Search for the First Free Village in Barbados, (9th Annual Conference of Caribbean Historians, Barbados 1977).

${ }^{231}$ The differences in topologies of the islands are well described in Goveia, supra note 230; Marshall, Ex-slaves, supra note 230; Riviere, supra note 230.

${ }^{232}$ GOVEIA, supra note 230; Marshall, Ex-Slaves, supra note 230.

${ }^{233}$ Marshall, Ex-Slaves supra note 230.
} 
almost entirely of flat arable land, nearly all land was consumed by the plantocracy. ${ }^{234}$

Thus, in the larger islands, the provisioning system was much more extensive. ${ }^{235}$ Slaves grew more food and the food markets were more plentiful. There were myriad cash crops that would allow for slaves to accumulate assets. Moreover, since manumission was ongoing (certainly up to the beginning of Apprenticeship), there were real incentives to accumulate cash. ${ }^{236}$ The bottom line: in the larger islands like Jamaica and Guyana, slaves were more likely to have cash because they had been serious market participants for some time. ${ }^{237}$

Thus, in sum my argument is that across the islands, one might envision a continuum, with "loyalty" and "voice" being more likely in the smaller islands and "exit" being more likely in the larger islands. The larger the likelihood was of "exit," the more quickly we are likely to witness the busting of racial cartels in plantation ownership.

A final point is in order: what happened with respect to property acquisition during slavery (when there were no formal protections) turns out to be singularly important. The irony is that the extensive nature of the provisioning system (with the extensive exposure that it provided slaves to informal property arrangements or a "property-lite") made it less likely that ex-slaves continued to remain in the employ of the masters once they had a real choice. Rather, because they had cash, they were well positioned to bust racial cartels in land ownership.

As we later see in New York, the key to busting racial cartels is white defectors. And at first the plantocracy seemed united in their view that newly freedmen would not get access to additional land. Moreover, even though the British Parliament passed the Amelioration Act ${ }^{238}$ which recognized various aspects of slaves' legal personhood, and which contained an apparently generous slate of property and contract rights, slaves rightly understood that the prospects for enforcement were poor.

After all, it was eminently clear that there would have been no Emancipation, had it been for the plantocracy. ${ }^{239}$ Emancipation had been

${ }^{234} \mathrm{Id}$.

235 GOVEIA, supra note 230.

${ }^{236}$ One need only consider that the purchase of freedom (not to mention the freedom of family members) became more expensive as early as the late $1700 \mathrm{~s}$, when it became apparent that the abolition of the slave trade (as opposed to slavery) was imminent (it ultimately happened 30 years before Emancipation in 1808). With the imminent abolition of the slave trade, planters were less inclined to entertain manumission since they rightly feared that they could no longer easily replenish their stock. See SHERLOCK \& BENNETT, supra note 204.

${ }^{237}$ See Rawle Farley, The Rise of the Peasantry in British Guiana, 2(4) SocIAL \& ECON. STUD., 87-103 (1954).

238 The Act was passed prior to the implementation of the mixed slave/mixed free labor period of Apprenticeship. Details and excerpts of the Act are included in THE SUGAR QUESTION: BEING A Digest of THE Evidence TAKen Before the COMMitTeE ON SugAR AND COFFEE PlantATIONS (Westminster: Parliamentary Reports, vol. 2 1848).

${ }^{239}$ There are several excellent histories of Slavery Abolition Act. For good introduction, see Christopher Leslie Brown, Moral CAPITAl: Foundations of BRitish Abolitionism (Chapel Hill: University of North Carolina Press 2006); WILliam Hague, WiLliam 
secured because of parliamentarians in Westminster who were somewhat removed from the weakened West Indian plantation interests. Enforcement of these newfound property and contract rights was a different matter; enforcement was up to the Colonial Office - staffed by civil servants based in the West Indies (far from London) who answered (in part) to the local legislatures (dominated by the plantocracy). Thus, whether or not these rights would be enforced was an open question. ${ }^{240}$

Moreover, setting aside questions of enforcement, even for those slaves who had assets, there remained questions of land availability. ${ }^{241}$ There were typically only two options for buying land, plantation lands and Crown (that is, government owned) lands. ${ }^{242}$ The availability of plantation lands would of course be determined by the plantocracy. And the availability of Crown lands would be determined by the Colonial Office. Here again, the parliamentarians in Westminster would be too far removed to help, even if they were so inclined. ${ }^{243}$

To achieve their goal of ensuring consistent access to low-cost labor, in many islands the planter-controlled Colonial legislatures, introduced policies of restricting freedmen's access to Crown lands by essentially pricing them out of the market. ${ }^{244}$ Additionally, the Colonial Governor (appointed in London, but typically close to the plantocracy) was typically empowered to raise the reserve price of Crown lands with little notice. ${ }^{245}$ Thus, if planters found themselves without access to consistent low-cost labor, the Colonial office would simply raise the price of land such that freedmen were no longer able to afford land. ${ }^{246}$

Simultaneously, groups of freedmen, determined to secure their own land, pooled their resources and banded together to locate lands to purchase. ${ }^{247}$ They would then appoint trusted leaders in the community to conduct land purchases on their behalf. ${ }^{248}$ Having located land, they were

Wilberforce: The Life Of THE GreAt ANTI-Slave Trade CAMPAIGNER, (Harper Press 2007); Adam Hochschild, Bury the Chains, The British Struggle to Abolish Slavery (Macmillan 2005). There are competing accounts of which factors most contributed to the demise of slavery including the decreasing dependence of the Treasury on taxes from sectors dependent on slavery, the declining interest of the plantocracy compared to other interests such as the free traders and the merchant class, the coalition of interests between the abolitionists and other sectors who for independent reasons sought to weaken the plantocracy, and the increasing influence of evangelical Christian abolitionists within the Church of England. Few dispute though that had it been left to the "West India" interests, abolition would have been - yet again - postponed. There was a widespread understanding among the slaves that they had been freed by the "Queen" (that is, the Crown), which they understood to be a distinct entity from local government, particularly given its domination by plantation interests.

${ }^{240}$ Holt, supra note 226.

${ }^{241} I d$.

${ }^{242} I d$.

${ }^{243} I d$.

${ }^{244} I d$.

${ }^{245} I d$.

${ }^{246} I d$.

${ }^{247}$ Brown, supra note 111.

${ }^{248} \mathrm{Id}$. 
empowered to purchase land in trust, and then sub-divide the land, so that each of the contributing freedmen would receive land according to his contribution to the larger pool of funds. ${ }^{249}$ Herein was the beginning of the land-brokering class.

For the planters to tie the slaves to the plantations, they needed to maintain a united front. More specifically, they needed to ensure that there was no land for the slaves to buy. But there was no sense in a strategy of precluding slave access to Crown lands if there were defectors (who were willing to sell to slaves).

Suffice it to say that within the plantocracy, defectors began to emerge. Because many of the freedmen had cash, a minority of planters rightly viewed the policy of restricting freedmen's access to land as foolhardy. Why not cash out?

Predictably, as we see later in New York, cracks began to appear in the racial monopoly in land ownership. The cash-rich trustee land-brokers were well positioned to close deals with defecting whites.

\section{CONCLUSION}

Rules matter, even if they are not embodied in formal law. The efficiency of black West Indians in acquiring property in their islands of origin was undergirded by a set of rules - namely rules, which solved collective action problems by allowing land brokers to buy land in trust on behalf of other West Indians while protecting future land-owners from unscrupulous trustees. Brokers had significant opportunities for opportunistic behavior. Yet, they rarely ran off with the money of their fellow West Indians, because such behavior would have entailed communal expulsion. Similar patterns are replicated when they arrive in New York City.

It bears emphasis that the legal-transplant literature is not a perfect fit. For example, I argue that there is not much in the way of "law," namely, state-backed rules, that were formally transplanted from the West Indian context to New York. Nevertheless, West Indians brought with them a robust set of norms which governed how they operated in housing and land markets.

One might think of West Indians as comparable to diaspora Chinese (in Indonesia, Phillipines and Malaysia to name a few countries) now famous in the law and development literature, ${ }^{250}$ or to the Maghribi Jews (in the

\footnotetext{
${ }^{249} I d$.

${ }^{250}$ Chua describes the diaspora Chinese as "market-dominant" minorities. She defines "marketdominant minorities" as "ethnic minorities who, for widely varying reasons, tend under market conditions to dominate economically, often to a startling extent, the 'indigenous' majorities around them." AMy Chua, World on Fire: How EXPORTING Free Market DEMOCRACY BREEDS ETHNiC HATRED AND Global Instability (2003). Take, for example, the Chinese in Malaysia. Despite constituting a mere 33 percent of Malaysia's population, Chinese holdings constitute over
} 
"Muslim West") for that matter. Diaspora minorities traded for decades (and indeed centuries), not only domestically but also transnationally. That is, they operated in complex capital markets, long before the development of formal commercial law, either domestically or transnationally.

There were rules that governed their transnational trade. That there rules were informal does not undermine their long-term effectiveness across borders and over centuries. These rules were very much legal transplants, even if they were largely informal.

One might think of West Indians as modern equivalents of Maghribi Jews ${ }^{251}$ Rules from a different place and time - allowed them to bust racial cartels in New York - decades, indeed centuries later.

70 percent of Malaysia's private economy. The numbers are stikingly similar for the Chinese in Indonesia, the Phillipines and Myanmmar, where they also are disproportionately likely to own large sectors of the economy. Id. They maintain this dominance in part because they are disproportionately likely to trade with other Chinese - both within their own countries and across borders. Id.

${ }^{251}$ The Maghribis were Jewish traders from the "Muslim West" who traded in a broad area ranging from northern Africa west of Egypt to Muslim Spain and Italy. By the eleventh century, they were trading throughout the Muslim Mediterranean, from Iberia to Constantinople. In this period, long distances and poor transportation made such trading difficult, yet they were able to maintain complex commercial transactions over long distances in large part because they largely restricted their trade to members of the same ethno-religious community. See Avner Greif, Contract Enforceability and Economic Institutions in Early Trade: The Maghribi Traders' Coalition, 83 AM. ECON. Rev. 525, 527-31 (1993); Avner Greif, Reputation and Coalitions in Medieval Trade: Evidence on the Maghribi Traders, 49 J. ECON. HIST. 857, 860-82 (1989); Avner Greif, Contract Enforcement and Institutions Among the Maghribi Traders: Refuting Edwards and Ogilivie, (CESifo, Working Paper No. 2350, July 2008). 